NÚMERO 523

JUAN ROSELLÓN, WOLF-PETER SCHILl AND JONAS EGERER

\title{
Regulated Expansion of Electricity Transmission Networks: The Effects of Fluctuating Demand and Wind Generation
}

\begin{abstract}
Importante
Los Documentos de Trabajo del CIDE son una hemamienta para fomentar la discusión entre las comunidades académicas. A partir de la difusión, en este formato, de los avances de investigación se busca que los autores puedan recibir comentarios y retroalimentación de sus pares nacionales e intemacionales en un estado aún temprano de la investigación.

De acuerdo con esta práctica intemacional congruente con el trabajo académico contemporáneo, muchos de estos documentos buscan convertirse posteriomente en una publicación formal, como libro, capítulo de libro o artículo en revista especia liza da.
\end{abstract}

DICIEMBRE 2011

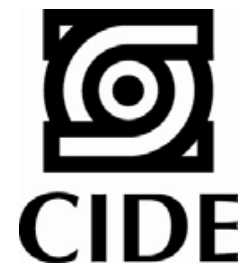

www. cide.edu 


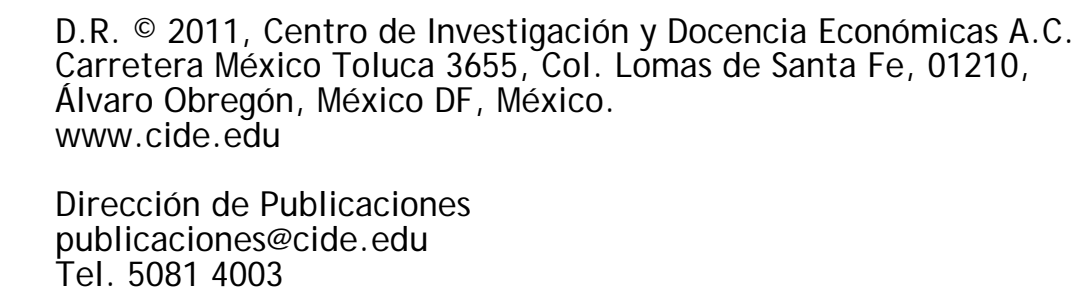


The authors would like to thank Christian von Hirschhausen for helpful comments. We also thank Özge Özdemir of ECN for providing us with network data. 



\begin{abstract}
We study the performance of different regulatory approaches for the expansion of electricity transmission networks in the light of realistic demand patterns and fluctuating wind power. In particular, we are interested in the relative performance of a combined merchant-regulatory mechanism compared to a cost-based and a merchant-like approach. In contrast to earlier research, we explicitly include both an hourly time resolution and fluctuating wind power, which allows representing demand in a very realistic way. This substantially increases the real-world applicability of results compared to previous analyses, which were based on simplifying assumptions. We show that a combined merchant-regulatory regulation, which draws on a cap over the two-part tariff of the Transco, leads to welfare outcomes far superior to the modeled alternatives. This result proves to be robust over a range of different cases and sensitivity analyses. We also find that the intertemporal rebalancing of the two-part tariff carried out by the Transco so as to expand the network is such that the fixed tariff part turns out to be relatively large compared to extension costs, a distributive issue that can be addressed through the proper choice of weight of profits in the welfare criterion.
\end{abstract}

Keywords: Electricity transmission expansion, incentive regulation, renewable integration, congestion management.

JEL Codes: L51, L91, L94, Q40.

Resumen

Estudiamos el desempeño de diferentes enfoques regulatorios para la expansión de las redes de transmisión eléctrica a la luz de patrones de demanda realistas y energía eólica fluctuante. En particular, estamos interesados en el desempeño relativo de un mecanismo combinado de mercado y regulatorio comparado con un enfoque basado en costos y otro de mercado puro. En contraste con la investigación reciente, incluimos explícitamente tanto una resolución por hora y energía eólica fluctuante, que permite representar a la demanda en una forma muy realista. Esto incrementa sustancialmente la aplicabilidad de los resultados en comparación a análisis previos, que se hacían con supuestos simplificadores. Mostramos que la regulación combinada de mercadoregulatorio que se sustenta en un tope sobre tarifas en dos partes de la Transco, lleva a resultados de bienestar mucho muy superiores a las alternativas modeladas. Este resultado es robusto sobre un rango de casos 
diferentes y bajo un análisis de sensibilidad. Asimismo encontramos que el rebalanceo intertemporal de la tarifa en dos partes es tal que el cargo fijo es relativamente grande en comparación con los costos de extensión, un tema distributivo que puede ser abordado mediante la elección apropiada del ponderador de los beneficios en el criterio de bienestar.

Palabras clave: expansión de la transmisión eléctrica, regulación por incentivos, integración de renovables, administración de la congestión.

Códigos JEL: L51, L91, L94, Q40. 
The European Union (EU) is currently undergoing a transformation of its energy system towards a sustainable and highly renewable-based system. The EU has set a three-fold goal for 2020: a 20\% share of renewables in energy consumption, a reduction of greenhouse gases by $20 \%$ with respect to 1990 , and an increase of energy efficiency by $20 \%$ In the long run, the EU targets a reduction of greenhouse gases by $80-95 \%$ by the year 2050. Most greenhouse gas emissions are related to energy utilization. A substantial transformation of the energy system is thus required, not only in Europe but world-wide. In particular, the European electricity systems should be largely carbon-neutral by 2050 in order to reach the ambitious two-degree-goal. Together with a substantial improvement of energy efficiency, a promising strategy for decarbonizing the electricity sector is the large-scale expansion of renewable energy sources (RES) like wind and solar power.

In particular, wind generation technology, which has a large natural potential, shows two main characteristics. On the one hand, typically the resources associated to this technology are unevenly geographically distributed. For example, in Europe growing shares of wind resources are mainly located at shorelines and off-shore. On the other hand, wind has severely fluctuating generation patterns. Its large-scale integration into electricity markets thus requires substantial upgrades and extension of existing transmission networks in order to connect distant generation sites, and even out regional imbalances due to those fluctuations. Since electricity transmission networks are natural monopolies, they need to be regulated so as to promote their expansion in a way that social welfare is also optimized. Network owners have no incentives for removing transmission bottlenecks if this reduces their profits (due to a loss in their congestion rents). This incentive structure is further complicated by asymmetric information between the network owner and the regulator. Thus, incentive compatible network expansion has to be ensured through economic regulation.

The regulation of transmission operation and expansion has been widely discussed by regulatory economists. Finding optimal mechanisms is difficult given the specific physical characteristics of electricity networks like negative local externalities due to loop flows, i.e. electricity flows obeying to Kirchhoff's laws. A range of different regulatory schemes and mechanisms have been proposed and applied so far. ${ }^{1}$ However, there is scarce research on optimal transmission regulation in the light of realistic demand patterns and large-scale RES integration. "Classic" regulation aims for expanding networks such that marginal arbitrage gains equal marginal expansion costs.

\footnotetext{
I See Hogan, W., J. Rosellón and I. Vogelsang (2010), Tanaka, M. (2007), Kristiansen, T. and J. Rosellón (2010),
} Léautier, T.-O. and V. Thelen (2009) and Léautier, T. O. (2000). 
Considering real-world demand fluctuations and RES-specific issues in network regulation analysis may require a different approach. In particular, the timing of electricity dispatch in RES systems is more frequent and fluctuating than transmission investment decisions.

In this paper we aim to enhance the economics understanding on how to regulate and expand transmission networks in the light of realistic demand patterns and large-scale wind power in Europe. We combine theoretical research on regulation of transmission expansion, with an application to Europe; we also derive policy implications. In order to analyze these issues, we initially rely on the Hogan-Rosellon-Vogelsang (HRV) mechanism ${ }^{2}$ which combines merchant and regulatory structures to promote the expansion of networks. Other extreme approaches to transmission expansion include the traditional central planning within a vertically integrated industry, and the pure market (or merchant) mechanisms. The HRV approach lies in between these two approaches, combining regulation (via price caps), and market incentives via property rights in electricity investment (financial transmission rights, FTRs). We aim to particularly analyze whether the unique variability and unpredictability characteristics of RES have an effect on transmission expansion decisions within the HRV analytical framework.

We are also interested in the relative performance of the HRV mechanism compared to other regulatory regimes for transmission network expansion, including a welfare-maximizing benchmark, a purely merchant approach, and cost regulation. We apply these mechanisms to a stylized model of the central European transmission network. The transmission model represents real power flows, which allows including special characteristics of electricity networks like loop flows. In contrast to earlier applications of the HRV mechanism, we explicitly include both an hourly time resolution and fluctuating wind power, which substantially increases the real-world applicability of the approach. We solve the model numerically and compare welfare outcomes and the optimal levels of network expansion for different cases that vary with respect to demand representation and wind power fluctuations.

We find that network extension in central Europe not only increases social welfare due to diminished congestion, but also leads to a large redistribution of social welfare from consumers to producers in France and Germany. Comparing different regulatory approaches, we find that HRV regulation leads to welfare outcomes that are close to the optimum achieved by a social planner, and far superior to other modelled alternatives. We show that this result is robust over all modelled cases. Our analysis thus quantitatively supports a theoretical claim according to which HRV regulation properly aligns a Transco's incentives with social welfare objectives. We also find that HRV regulation leads to a situation in which a substantial portion of the Transco's

2 Hogan, W., J. Rosellón and I. Vogelsang (2010). 
income consists of a fixed-tariff part. Likewise, the intertemporal rebalancing of the two-part tariff carried out by the Transco so as to expand the network is such that the fixed part is much higher than the decrease of the variable part. In fact, the fixed tariff fee turns out to be relatively large compared to extension costs, a distributive issue that can be addressed through the proper choice of weight of profits in the welfare criterion.

The remainder of the paper is structured as follows. Section 1 reviews the relevant literature. Sections 2 and 3 introduce the model and its application to a stylized central European example. Results are discussed in section 4. The last paragraph summarizes and concludes.

\section{The Literature}

There are two main distinct analytical approaches to transmission investment: one employs the theory based on long-term financial transmission rights (LTFTR, merchant approach), while the other is based on the incentive regulation hypothesis (performance-based-regulation, PBR, approach). The PBR approach to transmission expansion relies on incentive regulatory mechanisms for a transmission company (Transco). One example is Vogelsang (2001) where price-cap regulation solves the duality of incentives for the transmission firm both in the short run (congestion) and in the long run (investment in network expansion). ${ }^{3}$ Equilibrium for this duality has been studied by the peak-load pricing literature: in equilibrium, the per-unit marginal cost of new capacity must be equal to the expected congestion cost of not adding an additional unit of capacity. ${ }^{4}$ Alternative regulatory PBR approaches provide the firm with incentives to make efficient investment decisions through penalizing congestion. ${ }^{5}$ In the international practice, PBR schemes for transmission expansion have been applied in England, Wales and Norway to guide the expansion of the transmission network. ${ }^{6}$

In Vogelsang (2001) two-part tariff regulatory model, incentives for efficient investment in the expansion of the network are obtained by the rebalancing of fixed and variable charges while convergence to the steady state Ramsey-price equilibrium crucially depends on the type of weights used. Ramsey prices result from the solution of the program where a regulator seeks to maximize social welfare subject to the individual rationality constraint of a firm with increasing returns to scale. The prices are such that they differ from

\footnotetext{
3 Vogelsang, I. (200I).

${ }^{4}$ Crew, M.A., C.S. Fernando and P.R. Kleindorfer (1995).

5 Grande, O. S. and I. Wangesteen (2000), Léautier, T.-O. (2000), and Joskow, P. and J. Tirole (2005).

6 During the 1990s, an "uplift management rule" was applied in England and Wales (Léautier, 2000). Such a rule made the Transco responsible for the full cost of an "out-turn" plus any transmission losses. The out-turn defined the cost of congestion as the difference between the price actually paid to generators and the price that would have been paid absent congestion. In Norway, a revenue-cap approach -which precludes having to exactly define the output produced by a Transco- has also been used in practice (Jordanger and Grønli, 2000).
} 
marginal cost inversely proportionally to the elasticity of demand. A Laspeyres index weight (previous period quantity weight) promotes intertemporal convergence of transmission tariffs to Ramsey prices, while average revenue weights (endogenous current period quantity weights) cause divergence from the Ramsey equilibrium. ${ }^{7}$

The merchant approach to transmission expansion is based on auctions of LTFTRs. The long-run concept is important for transmission expansion projects for investors. Such projects usually have an installed lifetime of approximately 30 years, so that auctions allocate FTRs with durations of several years. Incremental LTFTRs implicitly define property rights. FTR auctions are carried out within a bid-based security-constrained economic dispatch with nodal pricing of an independent system operator (ISO). The ISO runs a power-flow model that provides nodal prices derived from shadow prices of the model's constraints. FTRs are subsequently derived as hedges from nodal price differences. Externalities in electricity transmission are mainly due to loop flows which arise from interactions in the transmission network. The effects of loop flows imply that transmission opportunity costs and pricing critically depend on the marginal costs of power at every location in the network. Loop flows generate negative externalities on property-right holders. In the merchant approach, the ISO retains some capacity or FTRs in order to deal with such externalities. Equivalently, the agent making an expansion is required to 'pay back' for the possible loss of property rights of other agents. ${ }^{8}$ In international practice, FTR auctions have been used in the North East of the USA (NYISO, PJ M ISO, New England ISO) and in California. ${ }^{9}$

A second-best standard that combines the merchant and PBR transmission models is proposed by the HRV model. This is done in an environment of price-taking generators and loads. A crucial aspect is the redefinition of the transmission output in terms of incremental LTFTRs in order to apply the basic price-cap mechanism in Vogelsang (2001) to meshed networks within a powerflow model. The Transco intertemporally maximizes profits subject to a cap on its two-part tariff, but the variable fee is now the price of the FTR output based on nodal prices. Again, the rebalancing between the variable and fixed charges promotes the efficient expansion of the network. The HRV mechanism has already been tested in model-based analyses for simplified grids in

\footnotetext{
7 Armstrong M., S. Cowan and J. Vickers (1994).

8 Bushnell, J. B. and S. E. Stoft (1997); Kristiansen, T. and J. Rosellón (2006).

9 FTR (or similar congestion revenue right) auctions have recently generated substantial revenues: USDI.9022 billion in PJM RTO, USD7I.I million in New England, and USD48.4 million in California (2009 data). In New England, the annual MW traded volume amounted 60,000MW in 2008 Data sources (accessed 02.10.2010): NYISO (New York ISO):

http://www.nyiso.com/public/markets_operations/market_data/tcc/index.jsp http://tcc.nyiso.com/tcc/public/view_awards_summary.do ISO-NE (New England ISO): http://www.iso-ne.com/markets/mktmonmit/rpts/other/amr09_final_05।8I0.pdf, CAISO (California ISO): http://www.caiso.com/2875/2875e49f6f870.pdf http://www.caiso.com/272b/272b8b042b7a0.pdf.
} 
Northwestern Europe and the Northeast USA. ${ }^{10}$ The testing of the HRV regulatory model results in the Transco expanding the network so that prices develop in the direction of marginal costs. The nodal prices that were subject to a high level of congestion before the expansion converge to a common marginal price level. In any case, these results show that the HRV mechanism has the potential to foster investment in congested networks in an overall desirable direction. ${ }^{11}$

In this paper we expand the HRV model so as to incorporate the peculiarities of real-world electricity systems and fluctuating renewables into the regulatory logic of the HRV model. In doing so, we also confirm the robustness of some key results obtained by Rosellón and Weigt (2011), which draw on a much simpler representation of demand, and on unrealistic initial price differences between countries. Likewise, we aim to also contribute with a novel application of combined regulatory-PBR mechanisms to the case of fluctuating and geographically dispersed renewables.

\section{The Model}

The model formulation builds on Rosellón and Weigt (2011). Table 8 in the Appendix lists all model sets and indices, parameters, and variables. We assume a market design with nodal pricing based on real power flows and financial transmission rights (FTRs). A single Transco holds a natural monopoly on the transmission network. The Transco decides on network extension and auctions off transmission capacity in the form of FTRs to market participants. Note that we do not explicitly model this point, but assume that FTR auction revenues are equal to congestion rents of the system. Accordingly, we just assume that the Transco maximizes profit, which consists of congestion rents and a fixed income part. Whereas the Transco is not involved in electricity generation, an independent system operator (ISO) manages the actual dispatch in a welfare-maximizing way. The ISO collects nodal payments from loads and pays the generators. The difference between these payments is the congestion rent. This congestion rent is transferred to the Transco. ${ }^{12} \mathrm{We}$ model three different regulatory cases in which we assume the Transco to be unregulated regarding network expansion (NoReg), cost-regulated (CostReg), or HRV-regulated (HRV). We compare these regulatory cases to a baseline case without any network expansion (NoExtension) and to a welfaremaximizing benchmark (WFMax), in which a social planner makes combined

\footnotetext{
10 Rosellón, J. and H. Weigt (20I0), "Rosellón, J., Z. Myslíková and E. Zenón (20II).

II The recently created Association of European Energy Regulators (ACER, to be fully operational in 20I I) seeks to achieve similar goals for European transmission grids.

12 More precisely, congestion rents are redistributed to FTR holders. The Transco's FTR auction revenues thus include these payments. As we do not explicitly model FTR auctions, we make the simplifying assumption that congestion rent is transferred to the Transco.
} 
decisions on network expansion and dispatch. The problem formulation entails two levels. In the regulatory cases, the Transco's profit maximization constitutes the upper-level optimization problem. In the welfare-maximizing benchmark, the upper-level problem represents the social planner's maximization problem. On the lower level, we formulate the ISO's welfaremaximizing dispatch as a mixed complementarity problem (MCP). The combination of lower and upper level problems constitutes a mathematical program with equilibrium constraints (MPEC). ${ }^{13}$

We assume a standard linear demand function (0.1):

$$
p_{n, t, \tau}=a_{n, \tau}+m_{n, \tau} q_{n, t, \tau}
$$

$p_{n, t, \tau}$ is the electricity price at node $n$ in regulatory period $t$ and hour $\tau$, whereas $q_{n, t, \tau}$ describes the corresponding electricity demand. Given (0.1), the lower level dispatch problem consists of equations (0.2)-(0.9). These represent an MCP formulation of the ISO's constrained welfare maximization problem, which is provided in the Appendix. Note that we model real load flows between single nodes with the simplified DC load flow approach developed by Schweppe et al. 1988 (compare also Leuthold et al. 2008). Note that equations (0.2)-(0.9) must be satisfied in every single hour $\tau$.

$$
\begin{array}{lr}
a_{n, \tau}+m_{n, \tau} q_{n, t, \tau}-p_{n, t, \tau} \leq 0 & \perp q_{n, t, \tau} \geq 0 \\
-C_{s}+p_{n, t, \tau}-\lambda_{4, n, s, t, \tau} \leq 0 & \perp g_{n, s, t, \tau} \geq 0 \\
-\sum_{l \in L} \frac{I_{l, n}}{X_{l, t}} \lambda_{1, l, t, \tau}+\sum_{l \in L} \frac{I_{l, n}}{X_{l, t}} \lambda_{2, l, t, \tau}-\sum_{n n} p_{n n, t, \tau} B_{n n, n, t}-\lambda_{5, n, t, \tau} \text { slack }_{n} \leq 0 \perp \Delta_{n, t, \tau} \geq 0 \\
\sum_{n} \frac{I_{l, n}}{X_{l, t}} \Delta_{n, t, \tau}-P_{l, t} \leq 0 & \perp \lambda_{1, l, t, \tau} \geq 0 \\
-\sum_{n} \frac{I_{l, n}}{X_{l, t}} \Delta_{n, t, \tau}-P_{l, t} \leq 0 & \perp \lambda_{2, l, t, \tau} \geq 0 \\
\sum_{s} g_{n, s, t, \tau}-\sum_{n n} B_{n, n n} \Delta_{n n, t, \tau}-q_{n, t, \tau}=0 & , p_{n, t, \tau} \text { free } \\
g_{n, s, t, \tau}-\bar{g}_{n, s} \leq 0 & \perp \lambda_{4, n, s, t, \tau} \geq 0 \\
\text { slack }_{n} \Delta_{n, t, \tau}=0 & , \lambda_{5, n, t, \tau} \text { free }
\end{array}
$$

Equations (0.2)-(0.4) represent the partial derivates with respect to $q_{n, t, \tau}$, $p_{n, t, \tau}$, and the voltage angle $\Delta_{n, t, \tau} \cdot I_{l, n}$ is the incidence matrix of the network,

13 Hobbs et al., (2000) were among the first to apply an MPEC approach to power market modelling. Gabriel and Leuthold $(2010)$ extend this approach by including integer constraints. 
which provides information on how the nodes are connected by transmission lines $l$. The parameter $X_{l, t}$ describes the reactance for each transmission line. $B_{n, n n}$ is the network susceptance between two nodes. Equations $(0.5)$ and (0.6) demand that the power flows on each line do not exceed the respective line's capacity $P_{l, t}$. (0.7) ensures nodal energy balance: generation minus net outflow has to equal demand at all times. Equation (0.8) constrains generation of technology $s$ to the maximum available generation capacity at the respective node. Finally, (0.9) establishes a point of reference for the voltage angles by exogenously setting the parameter slack $k_{n}$ to 1 for one node in the network. For all other nodes, slack ${ }_{n}$ equals 0.

Whereas the lower-level problem (0.2)-(0.9) has to be solved for every single hour $\tau$, the upper-level problem needs to be inter-temporally optimized over all regulatory periods $t$. For the three regulatory regimes, the upper level problem is represented by (0.10):

$$
\max \Pi=\sum_{t \in T}\left(\left(\sum_{\tau \in \mathrm{T}} \sum_{n \in N}\left(p_{n, t, \tau} q_{n, t, \tau}-\sum_{s \in S} p_{n, t, \tau} g_{s, n, t, \tau}\right)+\text { fixpart }_{t}-\sum_{l \in L} \sum_{t t<t} \operatorname{ec}_{l} \text { ext }_{l, t t}\right) \frac{1}{\left(1+\delta^{p}\right)^{t-1}}\right)
$$

The Transco's only decision variable is capacity extension of transmission lines ext $t_{l, t}$, which incurs extension costs $e c_{l}$ (annuities). In the NoReg case, transmission investments have to be fully recovered by congestion rents, i.e. fixpart $_{t}=0$. Accordingly, the Transco will only extend such lines that increase congestion rents. Both future revenues and future costs are discounted with a private discount rate $\delta^{p}$. In the CostReg case, we assume that the Transco not only receives congestion rents, but may also charge an additional fixpart which reimburses the line extension cost and grants an additional return on costs ("cost-plus" regulation). Equation (0.11) shows that the fixed part of a given period includes the costs (annuities) of all network investments made so far plus a return on costs $r$. With positive $r$, the Transco may find it optimal to expand all transmission lines infinitely. We thus include an additional constraint which states that equation $(0.11)$ only holds as long as line extension does not exceed the optimal levels as determined by the welfaremaximizing benchmark. ${ }^{14}$ In the HRV case, the Transco may also charge a fixed tariff part, on which equation (0.12) sets a cap. It includes previous period quantity weights (Laspeyres weights) ${ }^{15}$. It also includes a retail price index RPI and an efficiency factor $X .{ }^{16}$ Summing up, in both the CostReg and

\footnotetext{
14 Note that this requires the regulator to have sufficient knowledge on which lines should be increased.

15 Compare Rosellón and Weigt (2010).

${ }_{16}$ We set both RPI and $X$ to zero in the model application, as we assume real prices and neglect efficiency gains.
} 
the HRV case, the Transco is able to recover network extension costs by the fixed tariff part. In contrast, this is not the case in the NoReg.

$$
\begin{aligned}
& \text { fixpart }_{t+1}^{\text {CostReg }}=\sum_{l \in L} \sum_{t t<t+1} e c_{l} \text { ext }_{l, t t}(1+r) \\
& \frac{\sum_{\mathrm{n} \in \mathrm{N}} \sum_{\tau \in \mathrm{T}}\left(p_{n, t+1, \tau} q_{n, t, \tau}-\sum_{s \in S} p_{n, t+1, \tau} g_{s, n, t, \tau}\right)+\text { fixpart }_{t+1}^{H R V}}{\sum_{\mathrm{n} \in \mathrm{N}} \sum_{\tau \in \mathrm{T}}\left(p_{n, t, \tau} q_{n, t, \tau}-\sum_{s \in S} p_{n, t, \tau} g_{s, n, t, \tau}\right)+\text { fixpart }_{t}^{H R V}} \leq 1+R P I-X
\end{aligned}
$$

In the welfare-maximizing benchmark case, the upper level problem does not describe a Transco's profit-maximization, but a social planner's maximization of social welfare. It is described by $(0.13)$. Note that the social planner uses a social discount rate $\delta^{s}$ which may be smaller than the private discount rate $\delta^{p}$ used by a Transco.

$$
\max w f=\sum_{t \in T}\left(\left(\sum_{\tau \in \mathrm{T}} \sum_{n \in N}\left(a_{n, \tau} q_{n, t, \tau}+\frac{1}{2} m_{n, \tau} q_{n, t, \tau}{ }^{2}-\sum_{s \in S} c_{s} g_{s, n, t, \tau}\right)-\sum_{l \in L} \sum_{t t<t} e c_{l} e^{2 x t_{l, t t}}\right) \frac{1}{\left(1+\delta^{s}\right)^{t-1}}\right)
$$

In all cases, there are inter-period constraints on line capacity (0.14), line reactance $(0.15)$ and network susceptance $(0.16)$.

$$
\begin{aligned}
& P_{l, t+1}=P_{l, t}+e x t_{l, t} \\
& X_{l, t}=\frac{P_{l}^{0}}{P_{l, t+1}} X_{l}^{0} \\
& B_{n n, n, t+1}=\sum_{l} \frac{I_{l, n} I_{l, n n}}{X_{l, t+1}}
\end{aligned}
$$

In the numerical application, equations $(0.15)$ and $(0.16)$ are neglected in order to reduce complexity and improve the numerical solution process. Instead, line reactance and susceptance are assumed to be constant. In section 0 , we perform a sensitivity analysis in which equations $(0.15)$ and $(0.16)$ are included. It shows that the main results also hold under the simplifying assumption of exogenous reactance and susceptance. 


\section{Model application}

The five MPEC problems are implemented in the General Algebraic Modeling System (GAMS). They are numerically solved on a 64bit Linux System with the solver CONOPT3. We apply the model to a stylized transmission network of central Europe, which includes seven country nodes in Germany, France, Belgium and the Netherlands, eight auxiliary cross-border nodes, and twenty stylized transmission lines (FIGURE 1). In addition, there are eight auxiliary lines in France and Germany, which we assume not to be congested. Network data is derived from Neuhoff et al. (2005), who have used this network for a seminal model comparison analysis. The same network has been used by Rosellón and Weigt (2011).

FIGURE 1. THE STYLIZED CENTRAL EUROPEAN TRANSMI SSI ON NETWORK

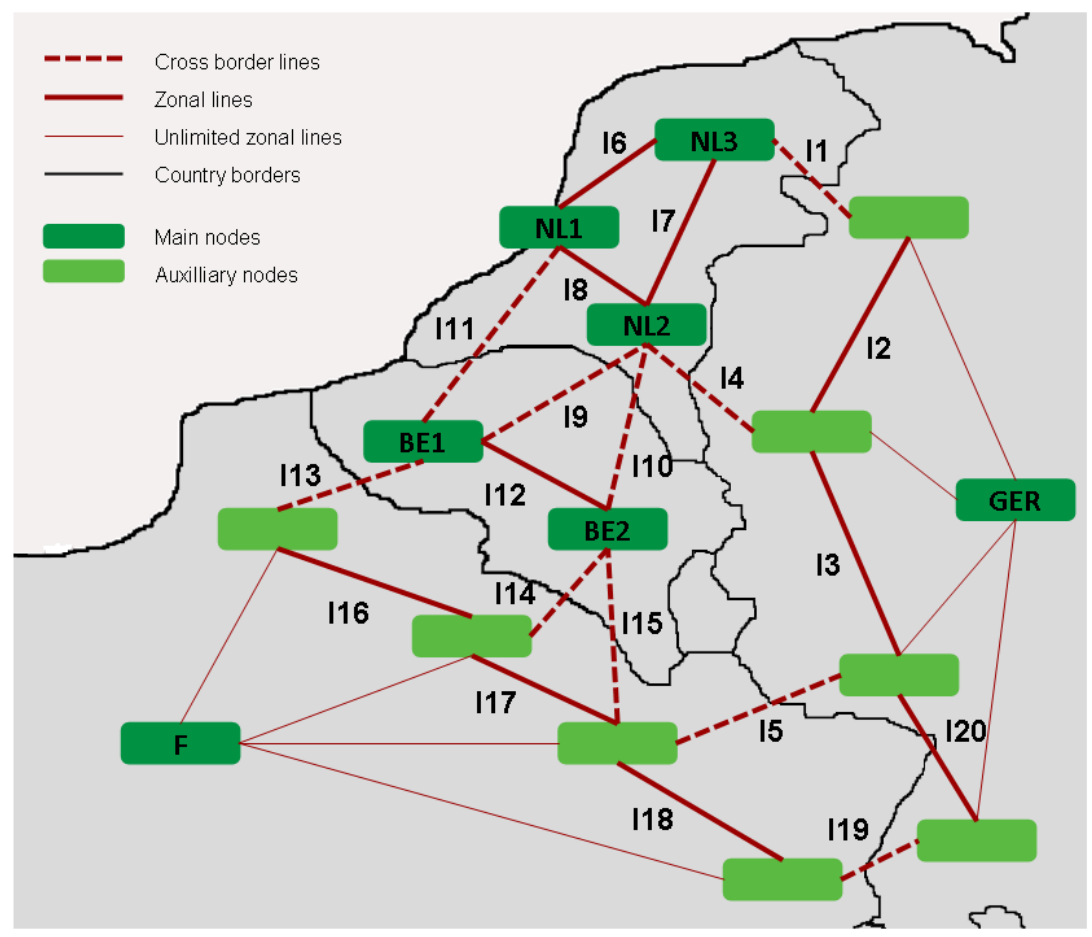

We include eight power generation technologies.

TABLE 1 lists variable generation costs and overall available capacity in the stylized network. Data sources include BP (2010), EEX (2010), ENTSO-E (2010a), Eurostat (2010) and IEA (2010). The values on available capacity also reflect own estimations on a part of the installed capacity not being available 
any given hour due to outages, seasonal maintenance and other technical restrictions. Table 9 in the Appendix shows nodal generation capacity in detail. $^{17}$

TABLE 1. VARI ABLE GENERATI ON COSTS AND AVAI LABLE CAPACITY

\begin{tabular}{|l|r|r|}
\hline TECHNOLOGY & $\begin{array}{c}\text { VARIABLE GENERATION COSTS } \\
\text { IN } € / \text { MWH }\end{array}$ & $\begin{array}{c}\text { OVERALL AVAILABLE } \\
\text { CAPACITY }\end{array}$ \\
\hline NUCLEAR & 9 & 64,858 \\
\hline LIGNITE & 29 & 15,120 \\
\hline HARD COAL & 35 & 35,064 \\
\hline CCGT & 43 & 16,358 \\
\hline GAS TURBINE & 65 & 16,286 \\
\hline OIL & 72 & 12,584 \\
\hline HYDRO & 0 & 9,841 \\
\hline WIND & 0 & 29,790 \\
\hline
\end{tabular}

We solve the model for three different cases that vary with respect to the time resolution of demand and wind generation.

TABLE 2Table 2 provides an overview. In the Static case, we assume average yearly demand levels, prices and wind generation. In the DRes case, demand is modeled on an hourly basis for six representative days of the year. We include both a weekday and a weekend day for each of three distinctive demand periods: summer (April to September), winter (November to February) and a shoulder period (March and October). We extrapolate to the whole year by weighting the six days with suitable factors. WindRes extends DRes by adding a fluctuating wind generation pattern derived from historic data. This approach allows to separate the effects of demand fluctuations and wind power fluctuations.

TABLE 2. OVERVI EW OF DI FFERENT CASES

\begin{tabular}{|l|l|l|}
\hline \multicolumn{1}{|c|}{ CASE } & \multicolumn{1}{|c|}{ REPRESENTATI ON OF DEMAND } & WI ND GENERATI ON \\
\hline STATIC & YEARLY AVERAGE & YEARLY AVERAGE \\
\hline DRES & 144 HOURS, REPRESENTING SIX CHARACTERISTIC DAYS & YEARLY AVERAGE \\
\hline WINDRES & 144 HOURS, REPRESENTING SIX CHARACTERISTIC DAYS & FLUCTUATING PATTERN \\
\hline
\end{tabular}

table 2 lists nodal reference demand and prices for the static case. Average yearly nodal demand levels have been calculated from hourly data for 2009 (ENTSO-E 2010b). Average yearly reference prices have been calculated from hourly spot market data for 2009 provided by EEX, EPEX and Belpex (day

17 The distribution of the total capacity among the different nodes on Belgium and the Netherlands is in line with original COMPETES data used in Neuhoff et al., (2005). 
ahead hourly auctions). In accordance with Rosellón and Weigt (2011), we assume a price elasticity of demand $\varepsilon$ of -0.25 at the reference point for all nodes and all hours. The average wind capacity factor is 0.172 for all nodes. This value has been calculated according to quarter-hourly feed-in data provided by the German TSOs for 2009.

TABLE 2: NODAL REFERENCE DEMAND AND PRI CES I N THE STATIC CASE

\begin{tabular}{|l|l|r|r|}
\hline NODE & DESCRI PTI ON & $\begin{array}{r}\text { REFERENCE DEMAND } \\
\text { IN MW }\end{array}$ & $\begin{array}{c}\text { REFERENCE PRICES IN } \\
\text { €/ MWH }\end{array}$ \\
\hline GER & GERMANY & 52,941 & 38.91 \\
\hline F & FRANCE & 55,748 & 41.61 \\
\hline BE1 & BELGIUM 1 & 6,893 & 39.39 \\
\hline BE2 & BELGIUM 2 & 2,822 & 39.39 \\
\hline NL1 & NETHERLANDS 1 & 7,839 & 39.13 \\
\hline NL2 & NETHERLANDS 2 & 1,573 & 39.13 \\
\hline NL3 & NETHERLANDS 3 & 2,759 & 39.13 \\
\hline
\end{tabular}

In the DRes case, nodal reference demand and prices are modeled on an hourly basis. We group hourly ENTSO-E demand data for the whole year 2009 in six different categories (weekdays and weekend days during summer, winter, and the shoulder period) and calculate average values for each hour of these six representative days. As shown in figure 2, this results in 144 representative hours which adequately represent a whole year. Hourly reference prices for the 144 hours are similarly determined drawing on hourly spot market data for 2009 provided by EEX, EPEX and Belpex. figure 2. HOURLY NODAL REFERENCE DEMAND IN DRES AND WINDRES

shows the resulting reference price pattern. ${ }^{18}$

18 The weighted averages of these I44 hourly values constitute the reference demand and reference price levels in the Static case. 
FI GURE 2. HOURLY NODAL REFERENCE DEMAND IN DRES AND WI NDRES

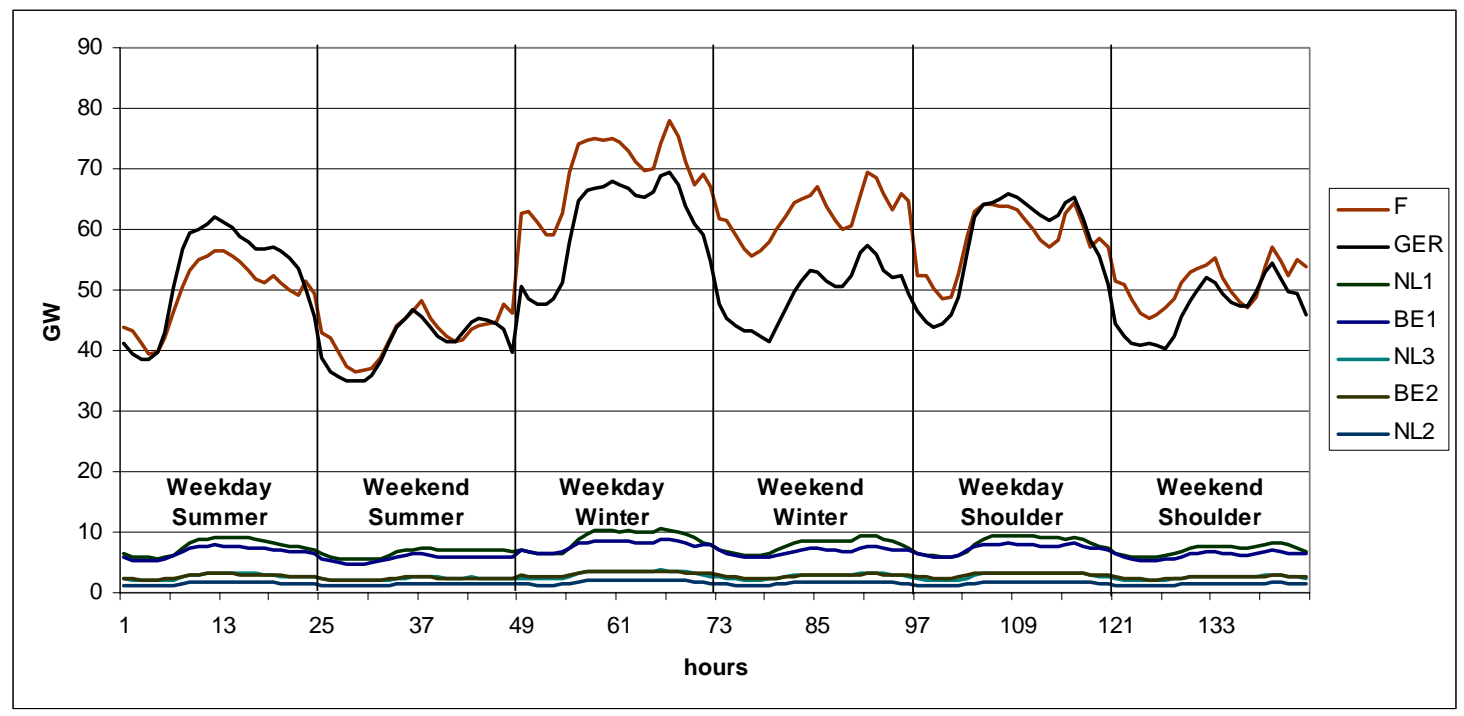

FI GURE 3. HOURLY NODAL REFERENCE PRI CES IN DRES AND WI NDRES

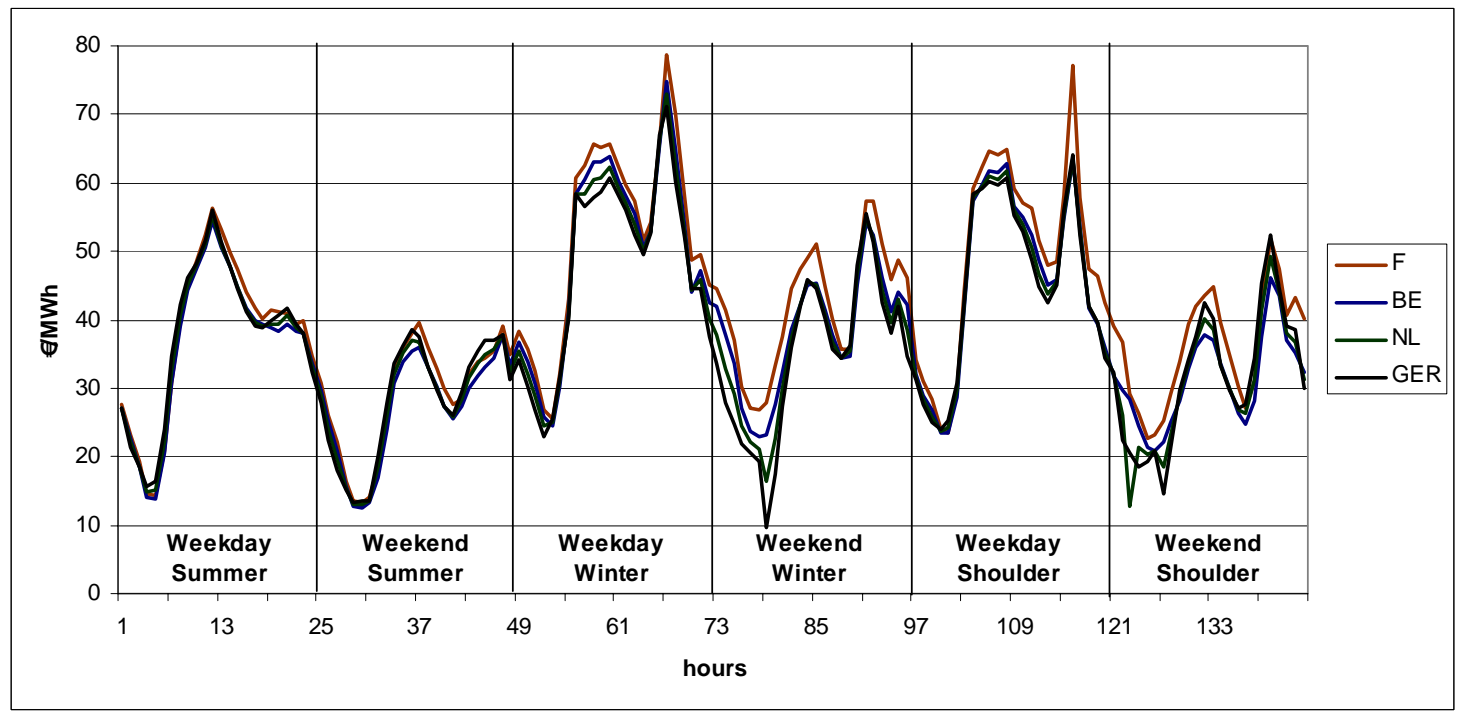

In the WindRes case, we draw on hourly German wind feed-in of 2009 provided by the German TSOs. ${ }^{19}$ We group hourly wind feed-in data of the whole year in six representative days (weekdays and weekend days during summer, winter, and the shoulder period). For each group, we sort the hourly

\footnotetext{
19 Because of a lack of data, we use the German wind feed-in pattern for the other countries, as well.
} 
wind values in ascending order and take 24 quantiles. These quantiles are randomly assigned to the 24 hours of each representative day. ${ }^{20}$ figure 4 shows the resulting wind pattern in the context of overall reference demand. Taking weighted averages of the resulting 144 representative hourly feed-in values leads exactly to the same overall wind feed-in as in the Static and DRes cases. Note that the wind feed-in pattern is completely unrelated to daily demand fluctuations. In contrast, there is a small seasonal correlation: during winter days, both demand and wind feed-in is higher than during summer days.

FI GURE 4. WI ND GENERATI ON AND OVERALL REFERENCE DEMAND IN WI NDRES

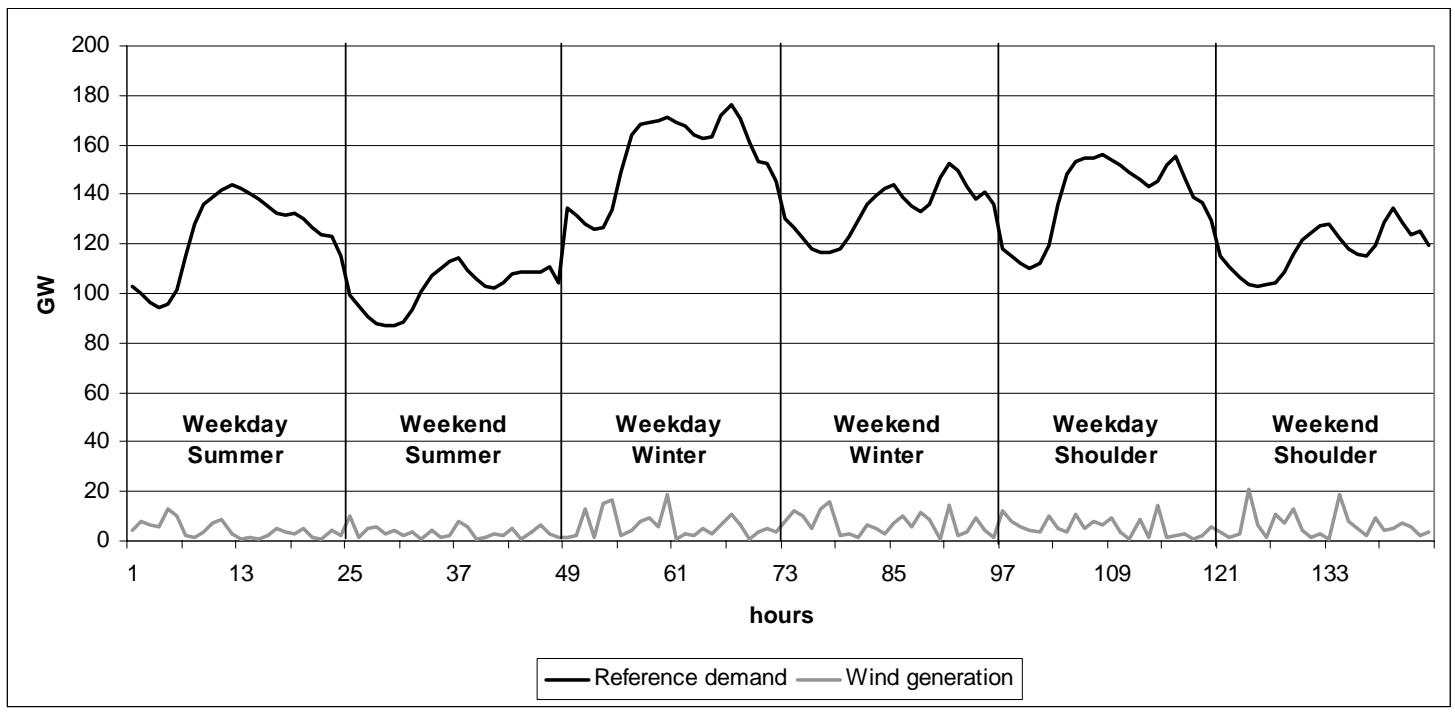

It should be noted that this wind pattern shown in figure 4 is not intended to resemble real-world wind feed-in during specific hours. Rather, it is intended to represent the characteristics of fluctuating wind generation during each of the representative six days. Over the 144 hours, many combinations of demand and wind generation occur, for example high wind / low demand or low wind / high demand. Overall, this approach captures the essentials of real-world wind power fluctuations quite well. Yet taking quantiles necessarily leads to an under-representation of hours with extremely high wind feed-in.

We solve the model for six regulatory periods (t0-t5), i.e. six years. ${ }^{21}$ Network expansion decisions can be made in the first period, but will become effective only in the second one. The social planner in the WFMax case applies a social discount rate $\delta^{s}$ of $4 \%$ for intertemporal optimization over the

20 Sensitivity tests have shown that other random assignments of hourly wind feed-in values lead to very similar results.

21 In a sensitivity analysis, we extend the time span to t0-t 10 . 
regulatory periods. In the following, we use the same discount rate for all comparisons of welfare outcomes. In the NoReg, CostReg and HRV cases, the Transco uses a private discount rate $\delta^{p}$ of $8 \%$ for intertemporal profit maximization. We further assume a return on costs $r$ in the CostReg case of $8 \%$

\section{Results}

\subsection{The simplified case}

First, we look at the Static case, in which neither demand nor wind fluctuate.

FIGURE 5 shows the locations and the levels of overall line extensions in the final period (t5) under all regulatory approaches. In the welfare-maximizing benchmark, the major extensions take place at the border between France and the Netherlands (lines 13, 14, and 15) and between Germany and the Netherlands (line 4). Under HRV regulation, exactly the same lines are expanded - largely at the same level as in WFMax. Cost-based regulation also leads to welfare-optimal expansion of most lines. However, the two lines that are most important for decreasing congestion rents are hardly expanded under CostReg: line 4 between Germany and the Netherlands and line 13 between France and Belgium. Substantially expanding these lines would lead to congestion rent losses that would by far outweigh the return on costs payed to the Transco for extending these lines. Under NoReg, hardly any network extension takes place as the Transco does not receive any payments that could outweigh congestion rest losses.

FI GURE 5. LI NE EXTENSI ON IN THE STATI C CASE

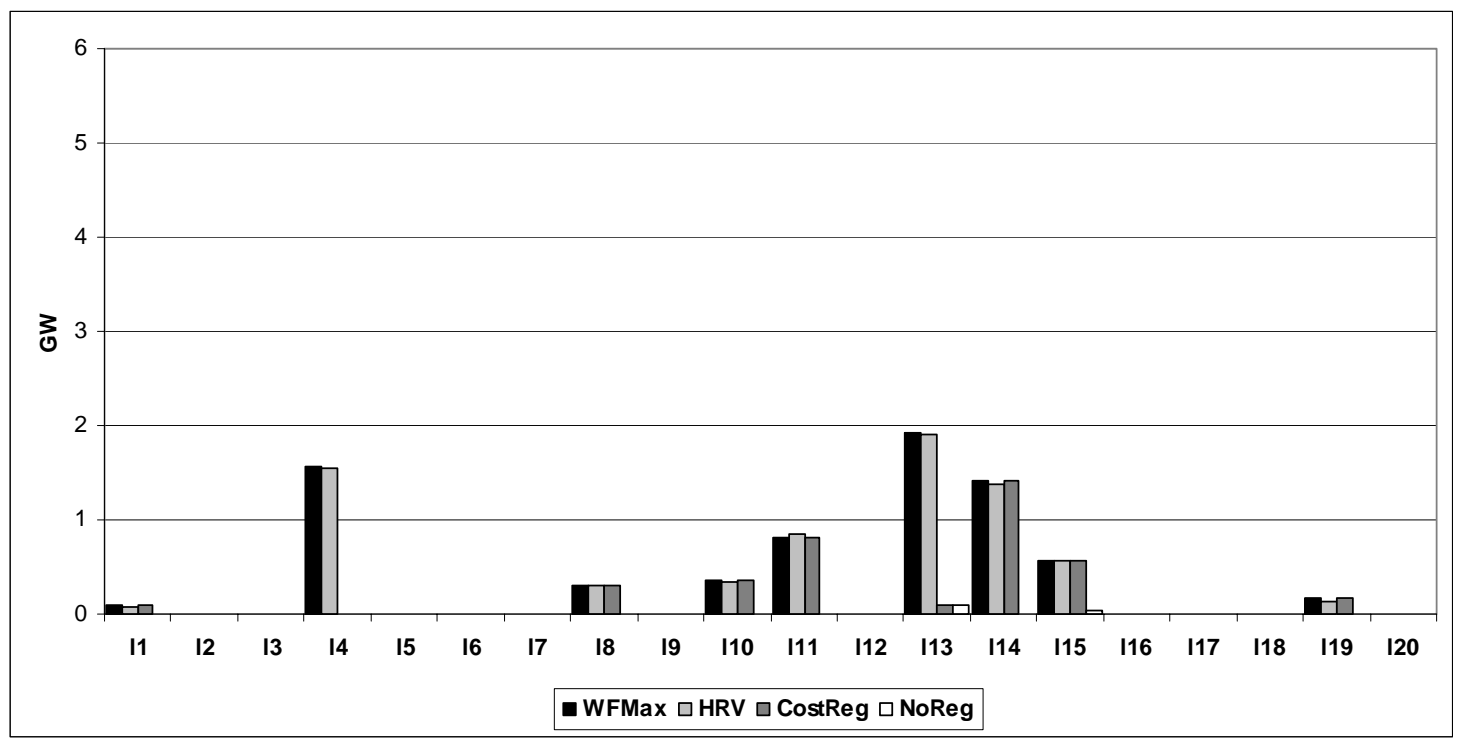




\section{While}

FIGURE 5 shows the final network expansion level in the final period (t5), it is also interesting to look at the time path of extension in the different cases. FIGURE 6 shows that all line extensions take place in the first period in the welfare-maximization benchmark. This result should be expected, as delaying investments would only decrease the benefits of extension measures. In the NoReg and CostReg cases, we find a similar result, although there is some activity between $\mathrm{t} 2$ and $\mathrm{t} 3$ in the cost-based regulatory case. In contrast, HRV regulation leads to incremental upgrades over the different regulatory periods. ${ }^{22}$ This result is driven by the yearly rebalancing of the variable and fixed parts of the two-part tariff according to equation (0.12). Accordingly, the full benefits of HRV regulation materialize in later periods.

FI GURE 6. TI ME PATH OF OVERALL EXTENSI ON IN THE STATI C CASE

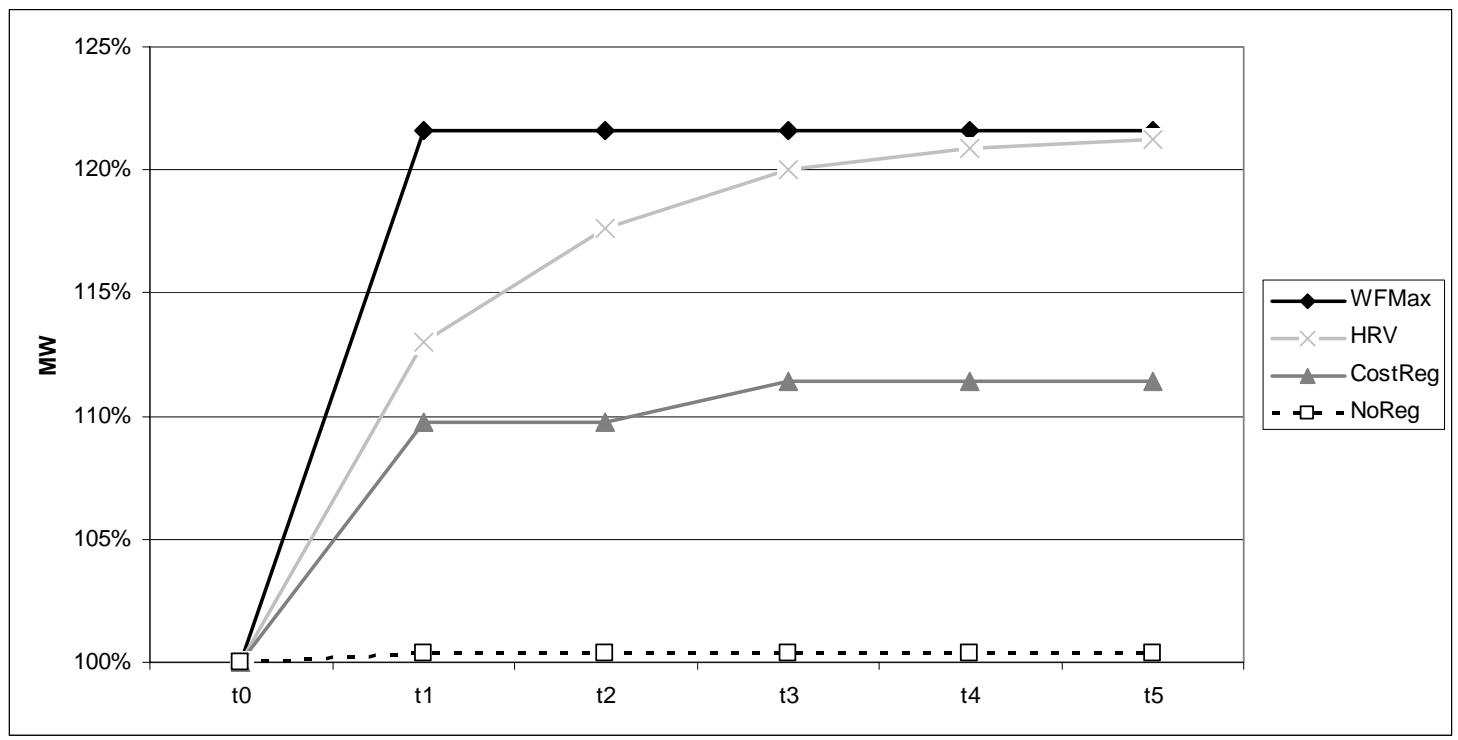

FIGURE 7 shows hourly nodal prices before and after network expansion under the different regulatory approaches. In the welfare-maximizing benchmark, price convergence is nearly perfect. Prices increase in France and Germany and decrease in Belgium and the Netherlands. In the HRV case, we find nearly the same results. Yet prices differ very much in the NoReg and CostReg cases. In these cases, the Transco expands the lines such that price differences between the most cross-border nodes increase. In doing so, the Transco manages to slightly increase congestion rents.

\footnotetext{
22 Note that we allow for continuous line extension. In the real world, line investments are lumpy. Accounting for indivisibilities may lead to different HRV results. Yet a numerical solution of a discretely constrained MPEC would be extremely challenging (compare Gabriel and Leuthold, 2010).
} 
FI GURE 7. CONVERGENCE OF NODAL PRI CES IN THE STATI C CASE
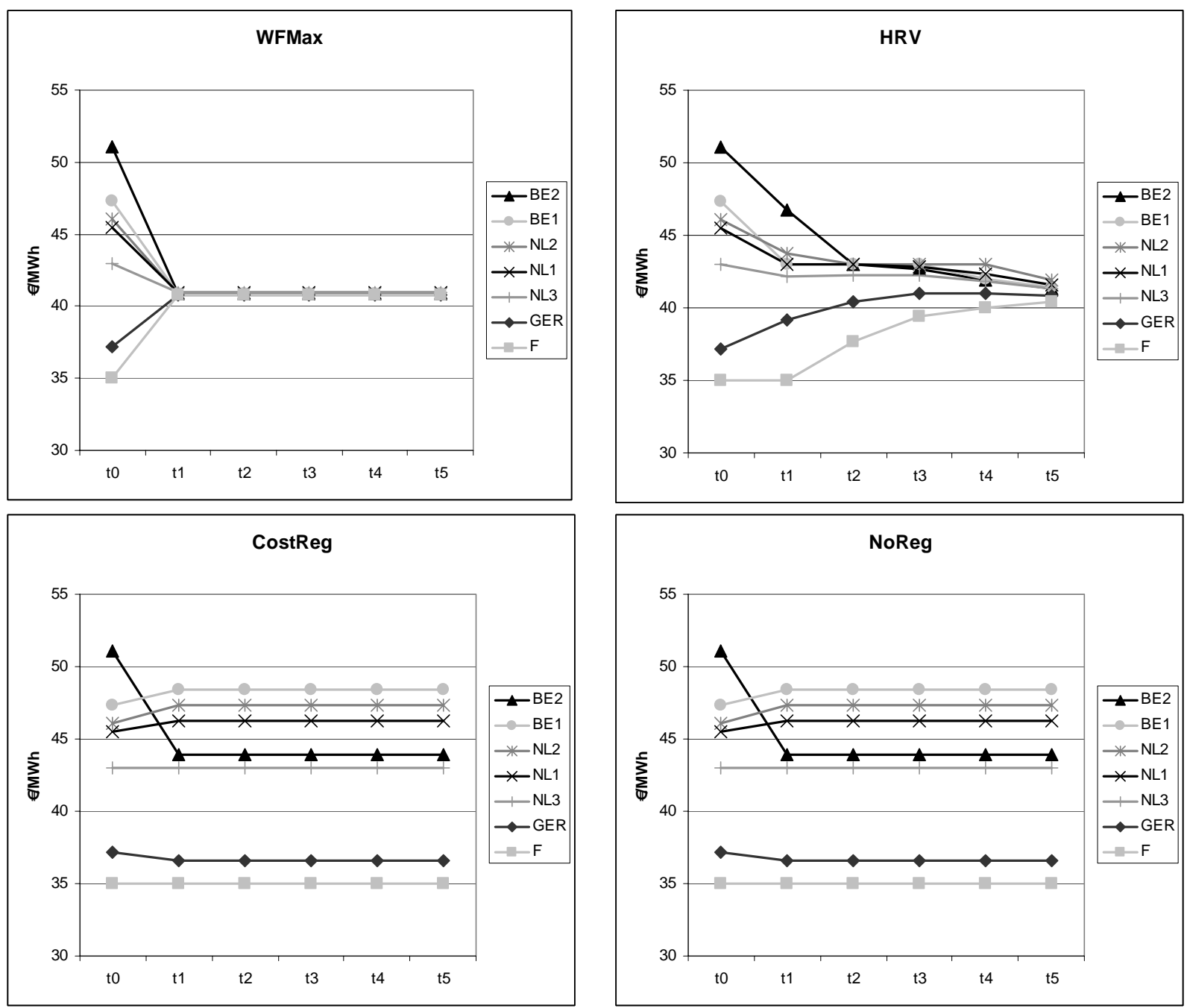

After analyzing line extensions and price effects, we look at welfare results. 
table 3 summarizes welfare outcomes for the Static case. ${ }^{23}$ It lists the differences to the baseline without extension (NoExtension) for the different regulatory approaches, i.e. the welfare gains of network extension. A general finding is that network expansion always increases social welfare compared to a situation in which extension is not possible.

${ }^{23}$ Note that the table lists cumulative welfare outcomes over all six modelled periods $(\mathrm{t} 0-\mathrm{t} 5)$. The same is true for the tables in the next sections. 
TABLE 3. WELFARE RESULTS STATIC: DI FFERENCES TO BASELINE WITHOUT EXTENSION IN BN $€$

\begin{tabular}{|l|r|r|r|r|r|r|r|}
\hline & $\begin{array}{c}\text { SOCI AL } \\
\text { WELFARE }\end{array}$ & $\begin{array}{c}\text { PRODUCER } \\
\text { RENT }\end{array}$ & $\begin{array}{c}\text { CONSUMER } \\
\text { RENT }\end{array}$ & $\begin{array}{c}\text { CONGESTI ON } \\
\text { RENT }\end{array}$ & $\begin{array}{c}\text { EXTENSION } \\
\text { COSTS }\end{array}$ & $\begin{array}{c}\text { TRANSCO } \\
\text { PROFIT }\end{array}$ & $\begin{array}{c}\text { FIXED } \\
\text { PART }\end{array}$ \\
\hline WFMAX & +1.94 & +19.04 & -15.57 & -1.50 & +0.03 & -1.50 & - \\
\hline NOREG & +0.13 & -1.42 & +1.36 & +0.19 & +0.00 & +0.19 & - \\
\hline COSTREG & +0.11 & -1.43 & +1.37 & +0.19 & +0.01 & +0.19 & +0.02 \\
\hline HRV & +1.81 & +13.08 & -11.13 & -0.12 & +0.02 & +1.68 & +1.82 \\
\hline
\end{tabular}

Looking at the welfare-maximizing benchmark (WFMax), we find a modest increase of social welfare of less than $€$ two billion over the five regulatory periods due to network expansion. However, there is a much larger distributional effect: producer rents are greatly increased, while consumer rents decrease. This effect can be explained by the fact that increased transmission capacities lead to additional exports from Germany and France and to respective price increases in these countries. Accordingly, consumer rents in Germany and France decrease, whereas consumers in Belgium and the Netherlands benefit from network expansion. As electricity consumption is much larger in Germany and France than in Belgium and the Netherlands, overall consumer rent decreases. Congestion rents (and Transco profits) also decrease due to network investments. ${ }^{24}$

Comparing social welfare among the different regulatory cases, we find that HRV regulation results in welfare outcomes close to the welfaremaximizing benchmark. In contrast, both NoReg and CostReg lead to much lower welfare gains of extension. Interestingly, the effects on producer and consumer rents are different compared to WFMax and HRV. This is because Transcos do not find it profitable to expand line 4 between Germany and the Netherlands in NoReg and CostReg. Consequently, German exports do not increase in these cases. In contrast, there is even a slight decrease of German exports under NoReg and CostReg due to investments in other lines. ${ }^{25}$

The extension-related decrease in congestion rents is largest in WFMax. HRV only leads to a small decrease in congestion rents, whereas NoReg and CostReg slightly increase network congestion. This is because small line upgrades lead to increasing trade, which outweighs a decreasing price difference between two congested nodes. In other words: profit-maximizing Transcos in NoReg and CostReg expand the network such that congestion is increased. In contrast, the HRV-mechanism gives the Transco an incentive to expand the network such that congestion is relieved. Accordingly, HRV

\footnotetext{
24 The Transco profit in the WFMax case is equal to congestion rents and just provided for reasons of comparison. Note the Transco profit is not maximized in this case.

25 This finding illustrates the merits of the DC load flow approach: Changes at remote nodes can have an impact on results at other nodes due to loop flows.
} 
regulation better aligns the Transco's incentives with social welfare objectives compared to NoReg and CostReg.

It can be observed that the rebalancing of the two parts of the tariff favors fixpart $_{t}$, as determined by equation (0.12), so that the Transco profits are highest in the HRV case. The fixed part is very large compared to extension costs and congestion rent losses. According to our results, the fixed part should be paid for by generators. Under both NoReg and CostReg, the Transco is hardly able to increase profits compared to NoExtension.

\subsection{The case with fluctuating demand}

We now discuss the DRes case, which has a much more realistic demand resolution than the Static case. figure 8 shows overall line extensions in the final period (t5) for DRes. In general, optimal line investments are much higher compared to the Static case. In addition, the major extensions take place at different lines. This is because fluctuating demand levels increase network congestion, particularly in peak hours. In the welfare-maximizing benchmark, we now find the major line investments at the border between Germany and France (lines 5 and 19). The lines with the major extensions in the Static case also play a role: lines at the border between France and the Netherlands (lines 13, 14 and 15) and between Germany and the Netherlands (line 4). In addition, extension of the lines between Belgium and the Netherlands (lines 10 and 11) is higher than in the Static case.

As before, we find that HRV regulation leads to an expansion of all the lines of the welfare-maximizing benchmark. However, HRV-triggered expansion is slightly less close to the welfare-optimum compared to the Static case. In the cost-based regulatory case, the Transco invests in all lines that are expanded in the welfare-maximizing benchmark. Some lines are even expanded beyond the welfare-optimal level because of an additional return on costs (lines 1, 8, and 9). Yet the lines that lead to the highest congestion rents are hardly expanded (lines $4,13,15,19$ ) $\rightarrow$ similar finding as in the Static case. Under NoReg, only minor network extension takes place. Under both NoReg and CostReg, the Transco tries to preserve as much fluctuationrelated congestion rent as possible. 
FIGURE 8. LINE EXTENSION IN THE DRES CASE

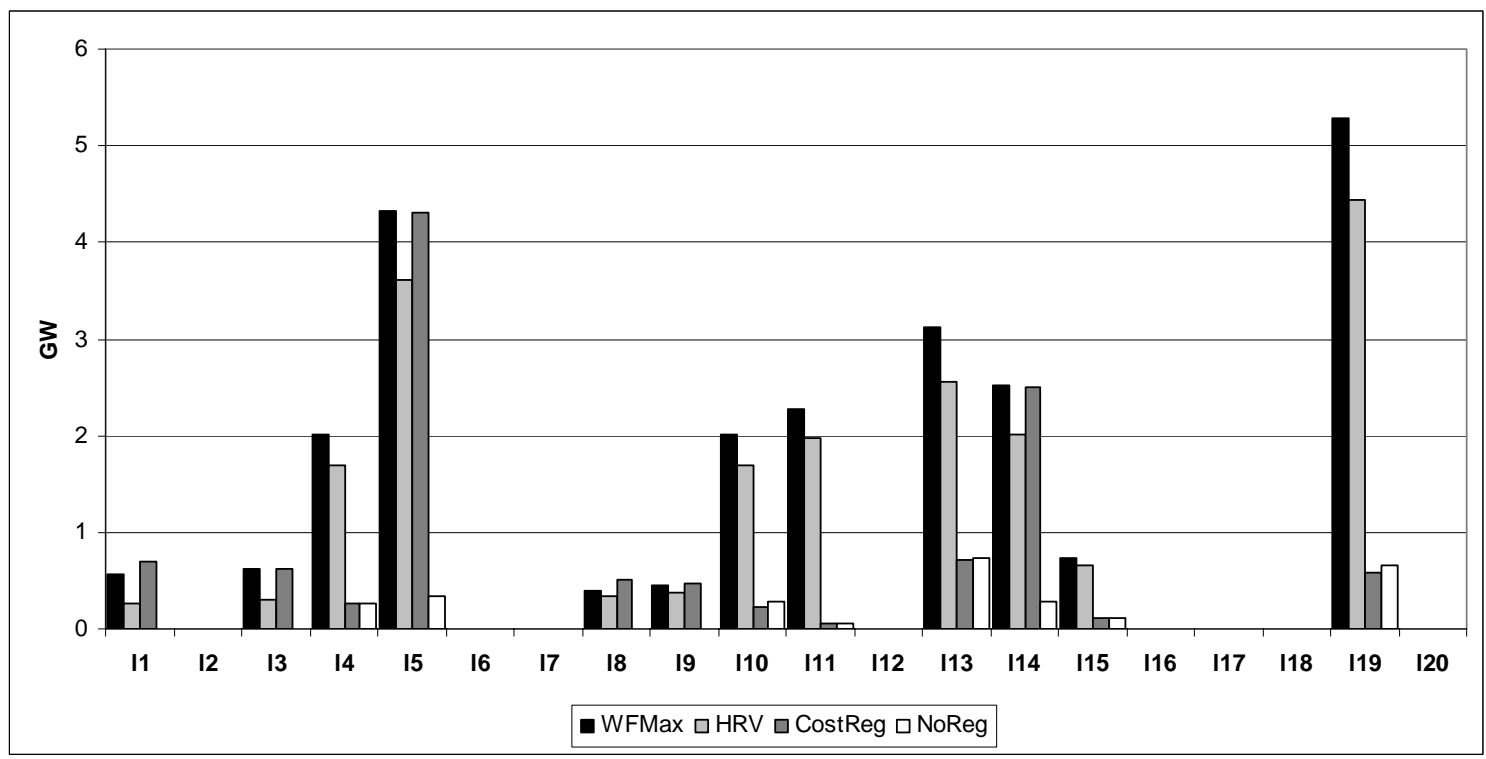

Figure 18 shows the time path of line extensions in the DRes case. While the general results are similar to the Static case, the overall level of network extension is higher. What is more, extensions under HRV regulation increase more slowly compared to the Static case. Obviously, HRV regulation needs more time to approach the welfare-optimal extension level in a more realistic setting.

FI GURE 9. TI ME PATH OF OVERALL EXTENSI ON IN THE DRES CASE

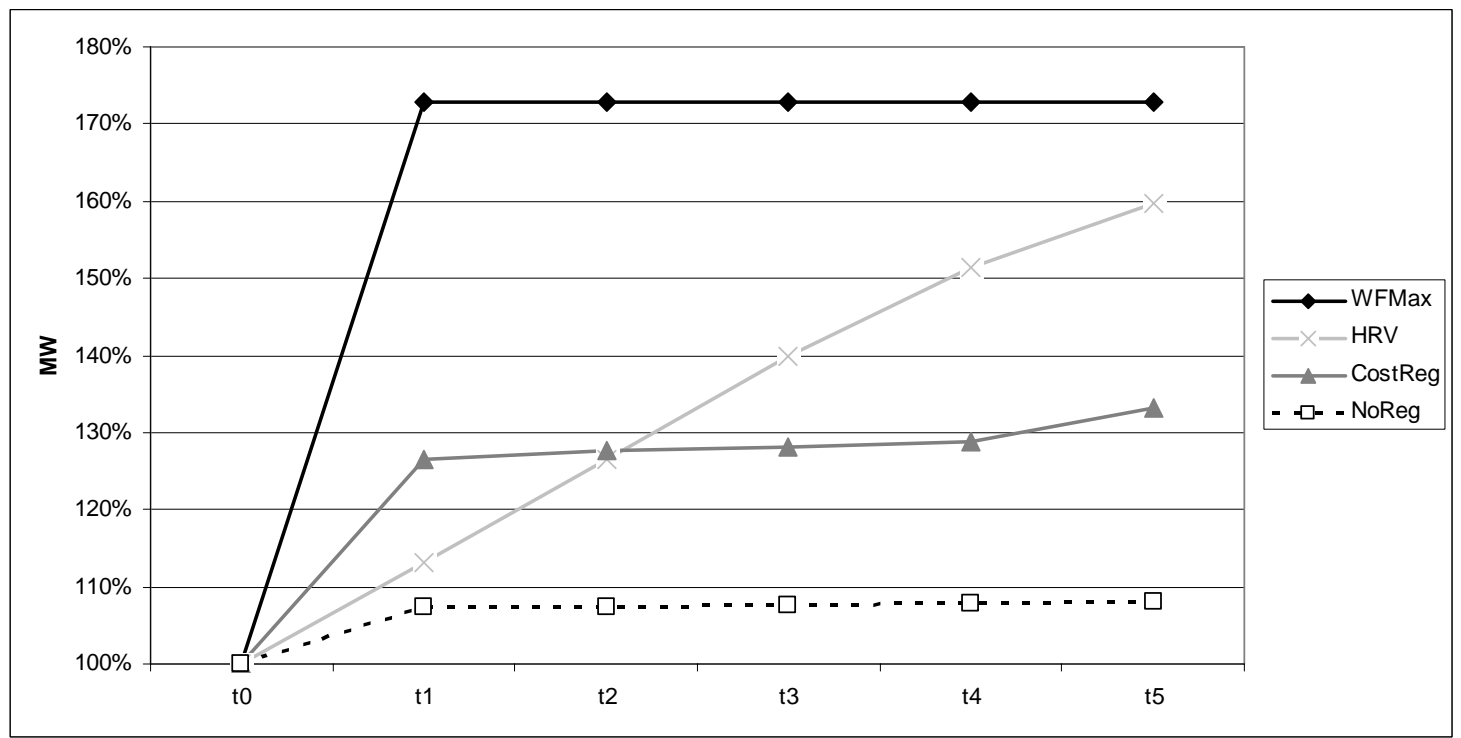


figure 10 shows hourly prices (six representative days) for Germany and France before and after network expansion. It can be seen that prices in Germany hardly change during most hours. Prices increase in winter peak periods due to additional exports, but decrease in summer off-peak periods due to imports of cheap base load power from France. French prices generally increase during summer because of exports of cheap base load power to the Benelux countries (and, to a lower extent, to Germany). During winter peak periods, French prices slightly decrease.

\section{FIGURE 10. HOURLY PRI CES IN FRANCE AND GERMANY BEFORE AND AFTER EXTENSI ON (DRES, WFMAX)}
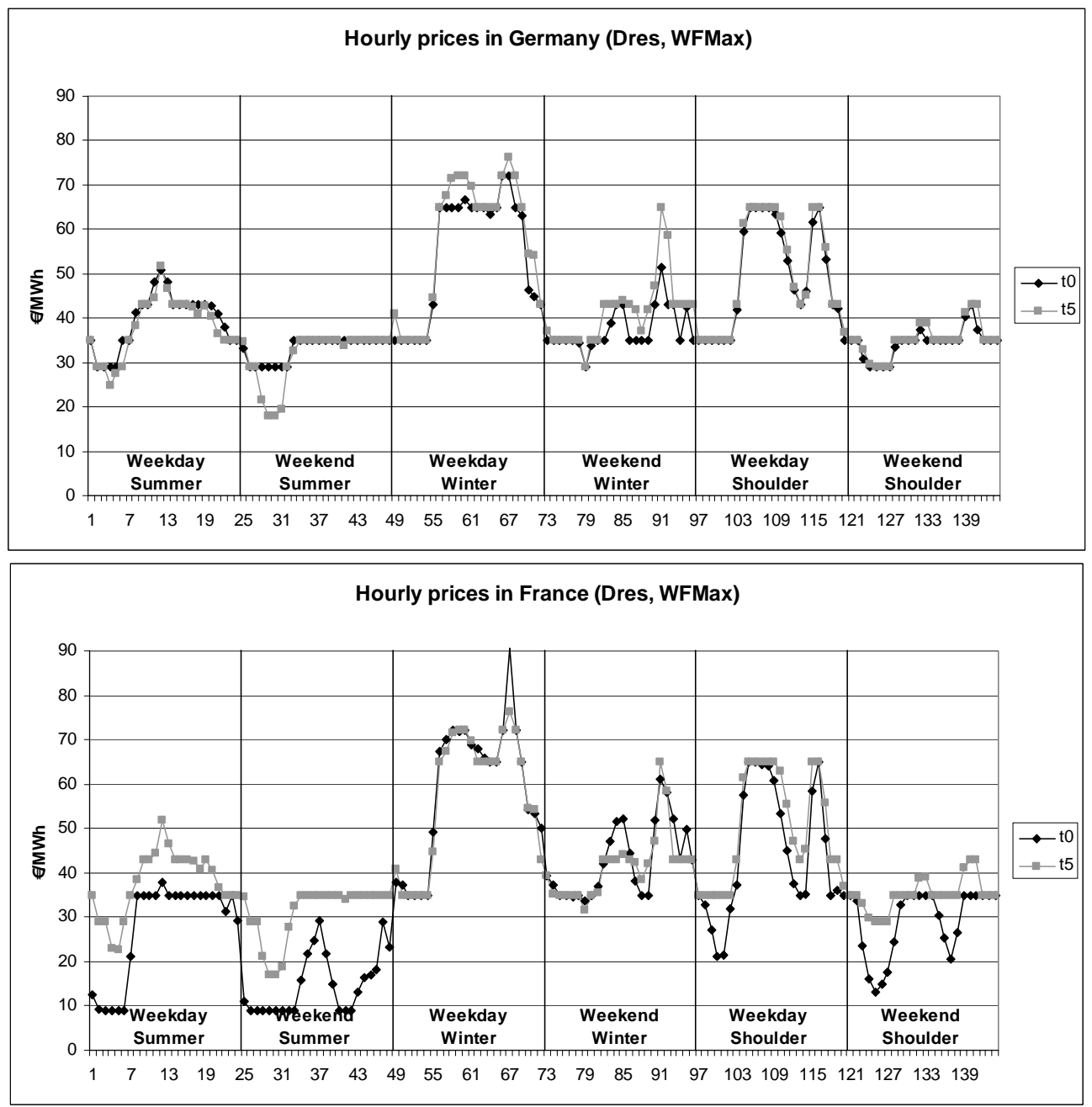

Figure 18 in the Appendix shows price convergence over all country nodes for the different cases. It can be seen that the high level of network expansion in WFMax leads to nearly perfect price convergence between the 
nodes during most hours. The same is true for the HRV case - with the exception of some off-peak prices, during which network congestion is lower. In contrast, both NoReg and CostReg lead to much lower price convergence, as the lines with the highest congestion rents are not sufficiently expanded in these cases. Price convergence in the DRes case is generally highest in winter peak periods and lowest in summer periods with lower demand levels. Given the price effects discussed above, Table 5 lists welfare differences between the different regulatory approaches and the baseline without extension for the DRes case. Looking at WFMax again, we find a larger social welfare gain of network investments compared to the Static case. Simplifying modeling assumptions may thus lead to a substantial underestimation of both expansion requirements and related welfare gains. The distributional effect of transmission investments on producer and consumer rents is qualitatively the same as in the Static case, but much less pronounced. In particular, consumer rents decrease less, as exports from Germany and France no longer increase in all periods. Congestion rents and Transco profits in WFMax decrease more than in the Static case due to higher network investments.

TABLE 4: WELFARE RESULTS DRES: DI FFERENCES TO BASELI NE WITHOUT EXTENSION IN BN $€$

\begin{tabular}{|l|r|r|r|r|r|r|r|}
\hline & $\begin{array}{c}\text { SOCIAL } \\
\text { WELFARE }\end{array}$ & $\begin{array}{c}\text { PRODUCER } \\
\text { RENT }\end{array}$ & $\begin{array}{c}\text { CONSUMER } \\
\text { RENT }\end{array}$ & $\begin{array}{c}\text { CONGESTION } \\
\text { RENT }\end{array}$ & $\begin{array}{c}\text { EXTENSION } \\
\text { COSTS }\end{array}$ & $\begin{array}{l}\text { TRANSCO } \\
\text { PROFIT }\end{array}$ & $\begin{array}{l}\text { FIXED } \\
\text { PART }\end{array}$ \\
\hline WFMAX & +2.80 & +11.13 & -5.97 & -2.27 & +0.08 & -2.27 & - \\
\hline NOREG & +1.10 & +1.82 & -1.13 & +0.42 & +0.01 & +0.41 & - \\
\hline COSTREG & +1.06 & +1.77 & -1.08 & +0.41 & +0.04 & +0.42 & +0.04 \\
\hline HRV & +2.25 & +6.59 & -3.62 & -0.68 & +0.04 & +1.79 & +2.51 \\
\hline
\end{tabular}

Comparing social welfare outcomes among different cases, we find again that HRV regulation is still closest to the welfare-maximizing benchmark, although HRV's relative welfare performance compared to WFMax slightly decreases from Static to DRes. The reason for this finding is that the network extension path approaches the social optimum more slowly. Both NoReg and CostReg once more lead to much lower welfare gains of extension, but to better results than in the Static case. We thus conclude that the positive welfare properties of the HRV mechanism are robust to modeling demand fluctuations.

Looking at congestion rents, results resemble the Static case, although they are more pronounced. The extension-related decrease in congestion rents is again largest in WFMax. HRV leads to a smaller decrease, whereas NoReg and CostReg once more increase network congestion. Note that network extension costs are roughly the same in CostReg and HRV, but social welfare outcomes of the HRV case are much better. As shown above, this is because the Transco has an incentive to invest in the wrong lines under 
CostReg. The fixed part that is necessary to align the Transco's incentives with a socially desirable extension path is even larger than in the Static case. The fixed part outweighs congestion rent losses, such that Transco profits are again highest under HRV regulation.

Given the findings discussed in this section, we conclude that using a detailed representation of demand has important implications for modeling transmission network expansion and for assessing the performance of different regulatory approaches.

\subsection{The case with fluctuating wind}

Finally, we examine the WindRes case, which includes not only demand fluctuations, but also fluctuating wind power feed-in. Line extensions in WindRes are very similar to the DRes case. As shown in

figure 11, we also find a similar extension path as in DRes, which approaches the welfare-optimal level, but does not yet reach it in the final period t5. Accordingly, including fluctuating wind power does not lead to major changes of extension results.

FIGURE 11. TIME PATH OF OVERALL EXTENSION IN THE WINDRES CASE

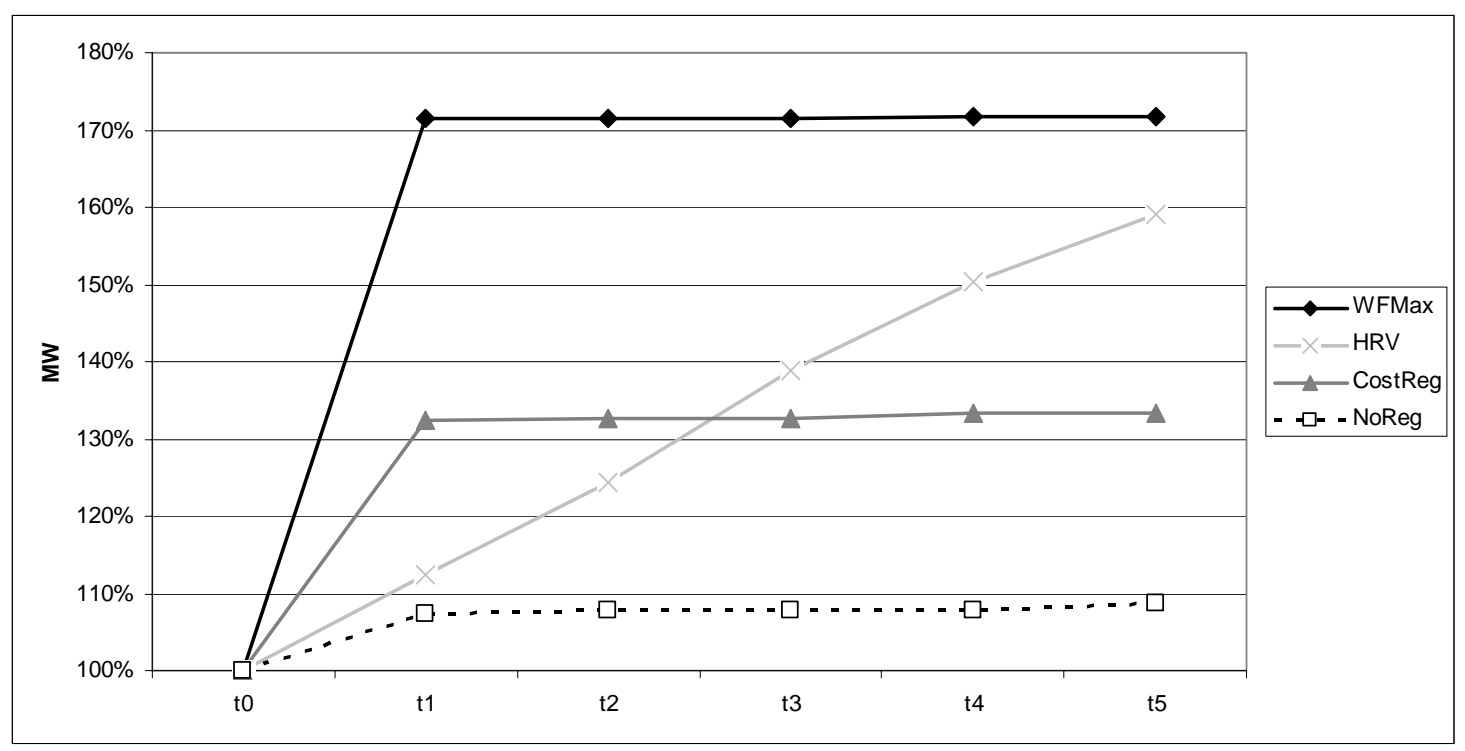

As for electricity prices, results are also similar to DRes, although we find slightly lower convergence in WindRes due to wind power fluctuations.

table 5 provides an overview of welfare results in the WindRes case. It can be seen that there are only small changes compared to DRes outcomes. In 
general, producers are slightly worse off compared to DRes, as wind peaks decrease prices in some periods.

TABLE 5. WELFARE RESULTS WINDRES: DI FFERENCES TO BASELINE WITHOUT EXTENSION IN BN $€$

\begin{tabular}{|l|r|r|r|r|r|r|r|}
\hline & $\begin{array}{c}\text { SOCI AL } \\
\text { WELFARE }\end{array}$ & $\begin{array}{c}\text { PRODUCER } \\
\text { RENT }\end{array}$ & $\begin{array}{c}\text { CONSUMER } \\
\text { RENT }\end{array}$ & $\begin{array}{c}\text { CONGESTION } \\
\text { RENT }\end{array}$ & $\begin{array}{c}\text { EXTENSION } \\
\text { COSTS }\end{array}$ & $\begin{array}{c}\text { TRANSCO } \\
\text { PROFIT }\end{array}$ & $\begin{array}{c}\text { FIXED } \\
\text { PART }\end{array}$ \\
\hline WFMAX & +2.82 & +11.46 & -6.31 & -2.25 & +0.08 & -2.33 & - \\
\hline NOREG & +1.09 & +1.81 & -1.15 & +0.44 & +0.01 & +0.43 & - \\
\hline COSTREG & +1.09 & +1.99 & -1.30 & +0.44 & +0.05 & +0.44 & +0.05 \\
\hline HRV & +2.30 & +6.80 & -3.69 & -0.76 & +0.04 & +1.79 & +2.59 \\
\hline
\end{tabular}

We conclude that including fluctuating wind power in the model leads only to small changes in the outcomes compared to DRes case. This result may be surprising at first glance, but can be explained by the relatively low importance of wind fluctuations in the light of the overall generation pattern in the central European electricity system of 2009. Accordingly, the beneficial welfare properties of the HRV mechanism also hold in a case with fluctuating wind power. From a modeling perspective, our results show that it is important to represent demand in a realistic way. If this is achieved, fluctuating wind power may be neglected - at least as long as its market share is as low as today. In section 0, we check if this results still holds under the assumption of much-increased wind generation capacity.

\subsection{The case with fluctuating wind}

\subsubsection{More regulatory periods}

Increasing the number of modeled regulatory periods does not change the general outcomes. The relative performance of HRV regulation slightly improves though, as the benefits of incremental network extension are larger in later periods. figure 12 shows that the network expansion in the HRV case is very close to the social optimum in the last regulatory periods. Modeling a smaller number of regulatory periods thus leads to an underestimation of HRV's welfare benefits. For t0-t5, HRV regulation achieves $80 \%$ of the extension-related social welfare gains of the welfare-maximizing benchmark in DRes. In the t0-t10 run, this number increases to $87 \%$ Accordingly, HRV's welfare implications are slightly better than suggested by the previously discussed results, if a more realistic time horizon is applied. 
FIGURE 12. TIME PATH OF OVERALL EXTENSI ON IN THE DRES CASE FOR TO-T10

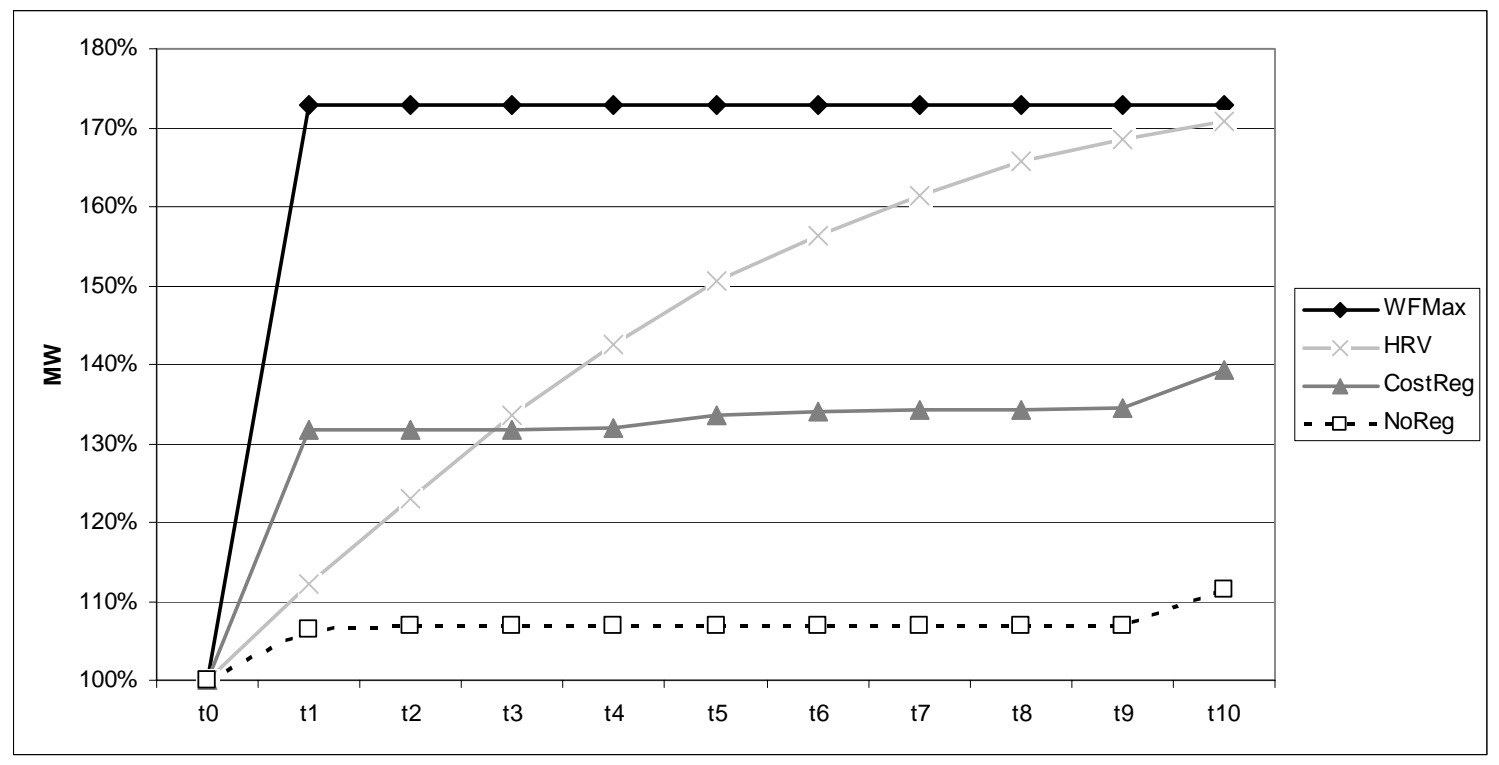

However, increasing the number of regulatory periods from six (t0-t5) to eleven (t0-t10) increases execution time for a full model run from around 70 hours to around 270 hours. As the major results do not change, we conclude that modeling t0-t5 is sufficient for the purposes of this paper.

\subsubsection{Higher extension costs}

We test the sensitivity of results to our assumption on network extension costs. All previous results have been calculated with costs of $100 € /(\mathrm{MW} * \mathrm{~km})$. This value reflects the costs of incremental upgrades of existing lines and has also been used by Rosellón and Weigt (2011). Yet incremental line upgrades may not always be possible. If it becomes necessary to build new lines from scratch, extension costs may be much higher. We test the effect of different values up to $1000 € /(M W * k m)$ for the DRes case. figure 13 shows that overall extension levels generally decrease with increasing costs. Yet larger cost assumptions decrease the gap between HRV extension results and WFMax: for values of $1000 € /(M W * k m)$, HRV regulation nearly achieves the welfareoptimal extension level. 
FIGURE 13. OVERALL EXTENSI ON IN DRES FOR DI FFERENT COST ASSUMPTI ONS

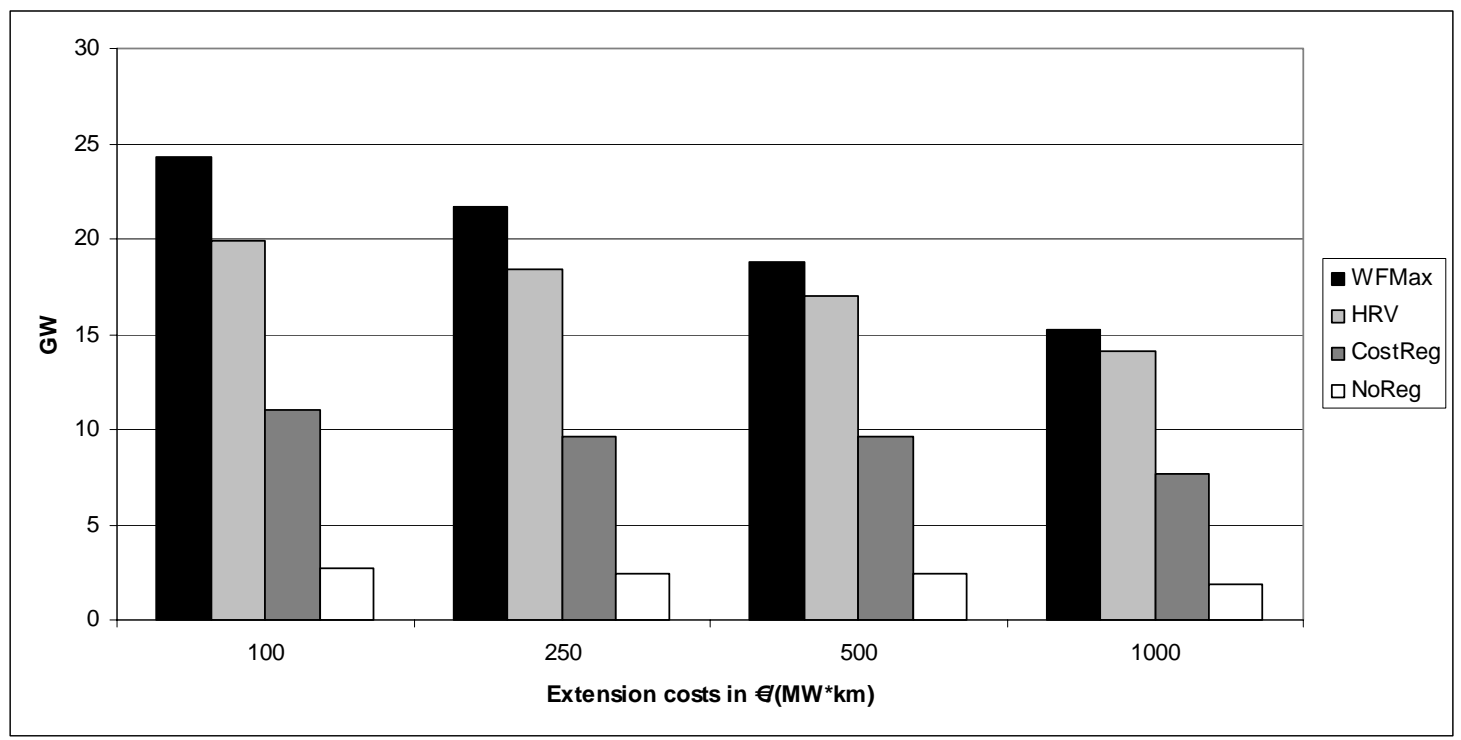

figure 14 shows the differences in social welfare for the different cases (differences to baseline without extension in bn $€$ ). While extension-related social welfare gains slightly decrease with increasing extension costs -due to lower extension-, the welfare findings discussed above are very robust.

FIGURE 14. WELFARE RESULTS DRES: DI FFERENCES TO BASELI NE WITHOUT EXTENSI ON IN BN $€$ FOR DIFFERENT EXTENSION COSTS ASSUMPTIONS 


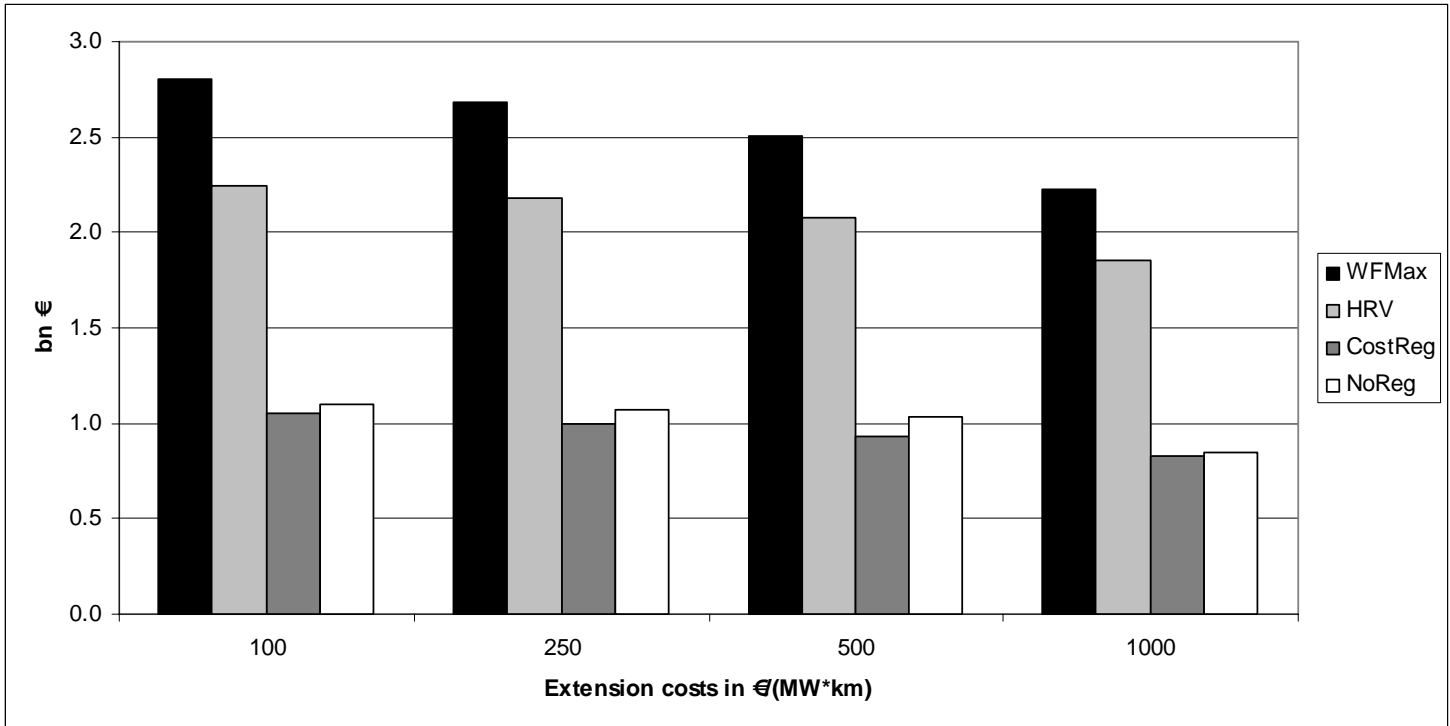

We conclude that increasing extension costs lead to a moderate decrease of network extension and moderate decrease of extension-related welfare gains in all cases. However, the general results do not change. In particular, the relative performance of the HRV mechanism compared to WFMax and to the other regulatory approaches is robust., Interestingly, the fixed tariff part under HRV regulation does not increase with increasing extension costs, but slightly decreases. Nonetheless, the fixed part is still substantially larger than extension costs even in the case with $1000 € /\left(M W^{*} \mathrm{~km}\right)$.

\subsubsection{Higher wind feed-in}

In section 0, we have shown that including fluctuating wind power at 2009 levels hardly changes results. We now check if this conclusion is still valid in a setting with much higher wind capacity. We assume that the available wind capacity in all nodes quadruples (WindRes_x4) and run the model again. figure 15 indicates the differences in line extension between the cases WindRes and WindRes_x4. It shows that increasing wind power increases the optimal amount of overall network investments because of higher (temporary) congestion. In particular, the cross-border lines between Germany and the Netherlands are being expanded (lines 1 and 4). This is because increasing wind capacity leads to a substantial price decrease in Germany - in which the largest wind capacity is assumed to be installed. Accordingly, network congestion between Germany and the Netherlands increases. In addition, lines within the Netherlands (lines 6 and 8) are expanded in order to transmit additional wind power.

FIGURE 15. LINE EXTENSION DI FFERENCES BETWEEN WI NDRES AND WINDRES_X4 


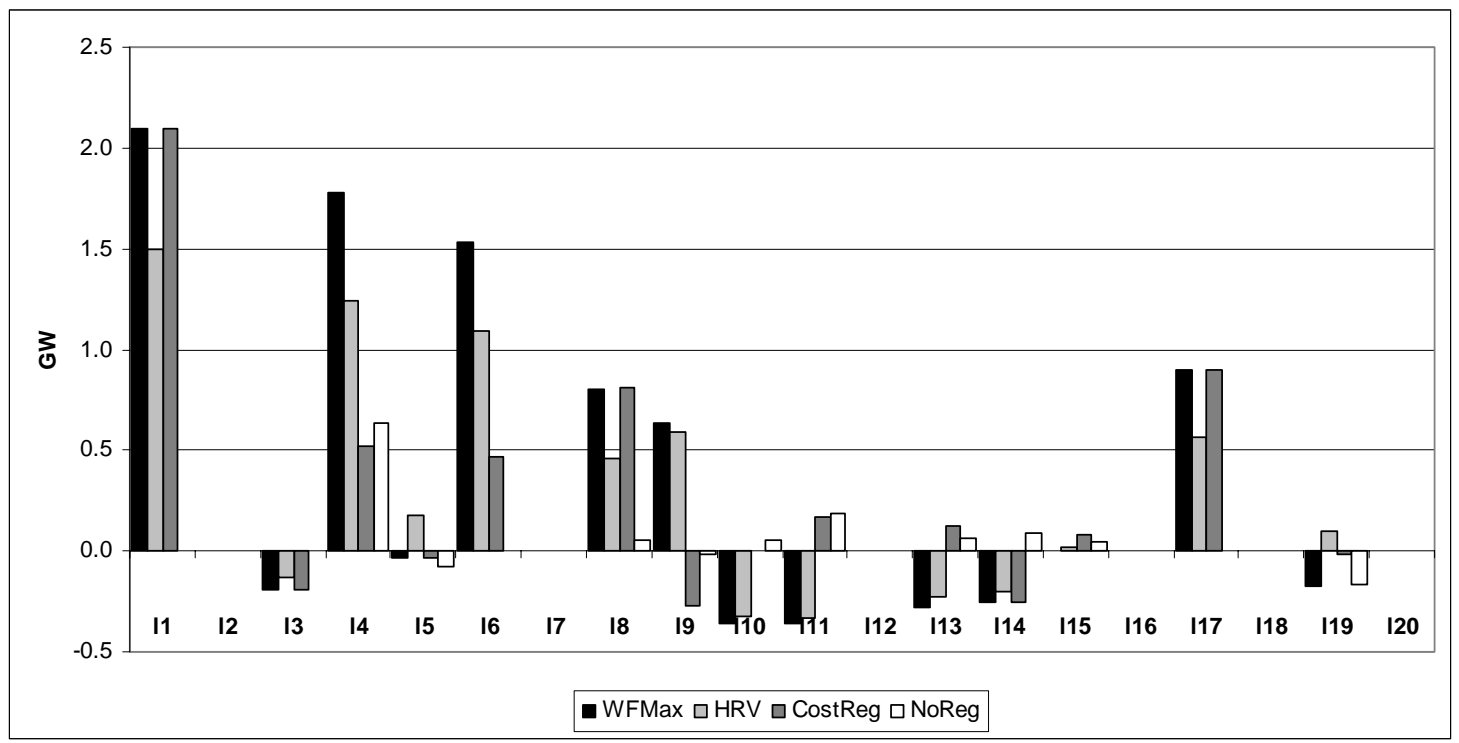

TABLE 6 shows the related welfare results. It can be seen that even under the extreme assumption of quadrupling wind power no general result changes signs compared to WindRes. As for social welfare, a larger capacity of unevenly dispersed wind power increases the welfare gain of network extension, as more congestion is relieved. The extension-related increase in producer rents is lower than in WindRes, whereas consumer rents decrease less. The reason for both effects is that the additional line expansion increases Germany's exports of cheap wind power, which in turn harms producers and benefits consumers in other countries. In both the welfaremaximizing benchmark and the HRV case, extension costs increase by around $30 \%$ compared to WindRes. However, the fixed tariff part, which is required to align the Transco's incentives with the socially preferable extension path, also increases to more than €3 billion over the six modeled regulatory periods.

TABLE 6: WELFARE RESULTS WINDRES_X4: DI FFERENCES TO BASELINE WITHOUT EXTENSION IN BN $€$

\begin{tabular}{|l|r|r|r|r|r|r|r|}
\hline & $\begin{array}{c}\text { SOCI AL } \\
\text { WELFAR }\end{array}$ & $\begin{array}{c}\text { PRODUCER } \\
\text { RENT }\end{array}$ & $\begin{array}{c}\text { CONSUMER } \\
\text { RENT }\end{array}$ & $\begin{array}{c}\text { CONGESTI ON } \\
\text { RENT }\end{array}$ & $\begin{array}{c}\text { EXTENSION } \\
\text { COSTS }\end{array}$ & $\begin{array}{c}\text { TRANSCO } \\
\text { PROFIT }\end{array}$ & $\begin{array}{r}\text { FIXED } \\
\text { PART }\end{array}$ \\
\hline WFMAX & +3.65 & +7.01 & -0.60 & -2.67 & +0.11 & -2.66 & - \\
\hline NOREG & +1.69 & +1.35 & -0.26 & +0.60 & +0.01 & +0.59 & - \\
\hline COSTREG & +1.67 & +1.44 & -0.32 & +0.60 & +0.05 & +0.60 & +0.05 \\
\hline HRV & +3.05 & +4.72 & -0.91 & -0.71 & +0.05 & +2.36 & +3.13 \\
\hline
\end{tabular}


4.4.4. Endogenous line reactance

All results discussed so far have been calculated under the assumption that line reactance does not change with capacity expansion. We perform a sensitivity analysis for all major cases under the more realistic assumption of endogenous line reactance according to equations (0.15) and (0.16). Figure 19 in the Appendix shows the differences in line extension between endogenous and exogenous line reactance for the cases Static, DRes, and WindRes. For the Static case, the major difference is that lines at the borders between Germany and the Netherlands (line1), Germany and France (lines 5 and 19), within Germany (lines 2 and 3), and within the Netherlands (line 8) are being expanded under NoReg. Note that none of these lines is congested, i.e. expanded in the welfare-maximizing benchmark. By upgrading these lines, the Transco manages to substantially increase network congestion on other lines, more precisely between France and Belgium and between Belgium and the Netherlands. In other words, including endogenous line reactance opens up new market power potentials for the Transco. As a consequence, NoReg leads to less desirable outcomes than in the simplifying runs with constant line reactance. Under CostReg, the Transco cannot apply this strategy, as it is only allowed to invest in the lines that are being expanded in the welfaremaximizing benchmark. Figure 19 shows that the effects in both the DRes and the WindRes case are less straightforward. Considering endogenous line reactance increases the optimal extension level for some lines, but decreases it for others.

As for welfare outcomes, results do not change much between endogenous and exogenous line reactance. figure 16 shows differences in social welfare for all regulatory cases. The only major differences concern HRV and NoReg in the simplified Static case. Here, modeling endogenous reactance moderately decreases the social welfare gain of extension compared to assuming exogenous reactance. Accordingly, we may have overestimated HRV's performance in the Static case (although HRV still leads to much better welfare results compared to CostReg and NoReg). However, a major point of this paper is that the simplified Static case leads to misleading results, anyway, and that it should be substituted by the more realistic DRes and WindRes cases. In these cases, we find hardly any social welfare differences between the runs with endogenous and exogenous line reactance. The same is true for producer, consumer and congestion rents.

FIGURE 16. SOCIAL WELFARE DI FFERENCES BETWEEN ENDOGENOUS AND EXOGENOUS REACTANCE FOR STATIC, DRES, AND WI NDRES 


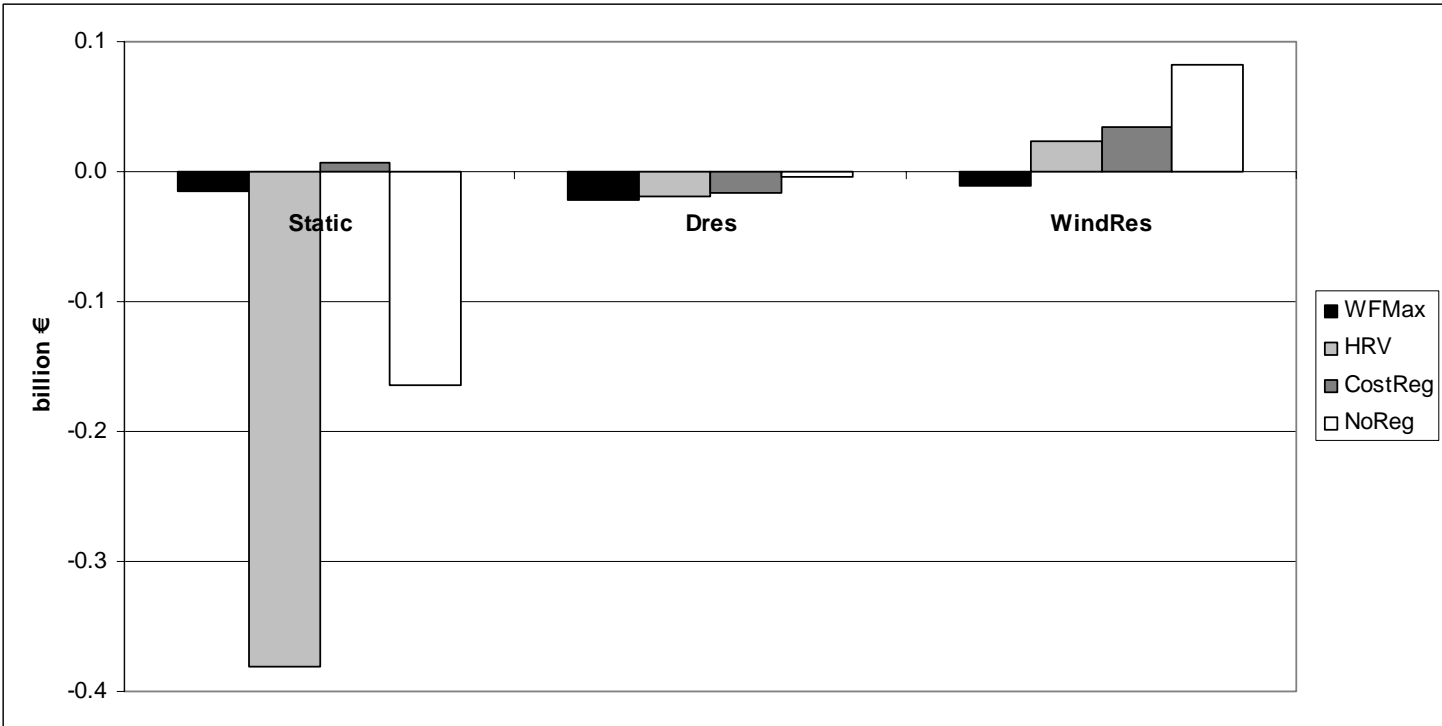

Given these results, we conclude that modeling endogenous line reactance has an impact on the locations and the levels of line extension in the different cases. Yet the welfare findings in DRes and WindRes are very similar to the ones determined under the assumption of exogenous line reactance. Making line reactance an endogenous variable substantially increases execution time for a full model run from around 70 hours to more than 230 hours the DRes case. In addition, finding globally optimal solutions gets more challenging. Given the robustness of welfare results, we conclude that our simplifying assumption of exogenous line reactance is justified in order to get meaningful solutions in acceptable execution time.

\subsubsection{A robust finding: HRV's welfa re properties}

figure 17 gives an overview of extension-related social welfare gains in all modeled cases relative to the respective welfare-maximizing benchmark (WFMax $=100 \%$ ). We find that the relative welfare outcomes are very robust over all model runs. HRV regulation is always closest to the welfare optimum. In particular, HRV achieves at least $80 \%$ of the socially optimal welfare gains in the DRes and WindRes cases with realistic representations of fluctuating demand and wind power. In contrast, both NoReg and CostReg lead to much lower welfare gains, whereas the NoReg case -which refrains from incentivizing investments-is slightly superior to cost-based regulation in most cases (except the Static case with endogenous line reactance).

FIGURE 17. SOCIAL WELFARE GAIN OF EXTENSI ON COMPARED TO WFMAX FOR DI FFERENT MODEL RUNS 


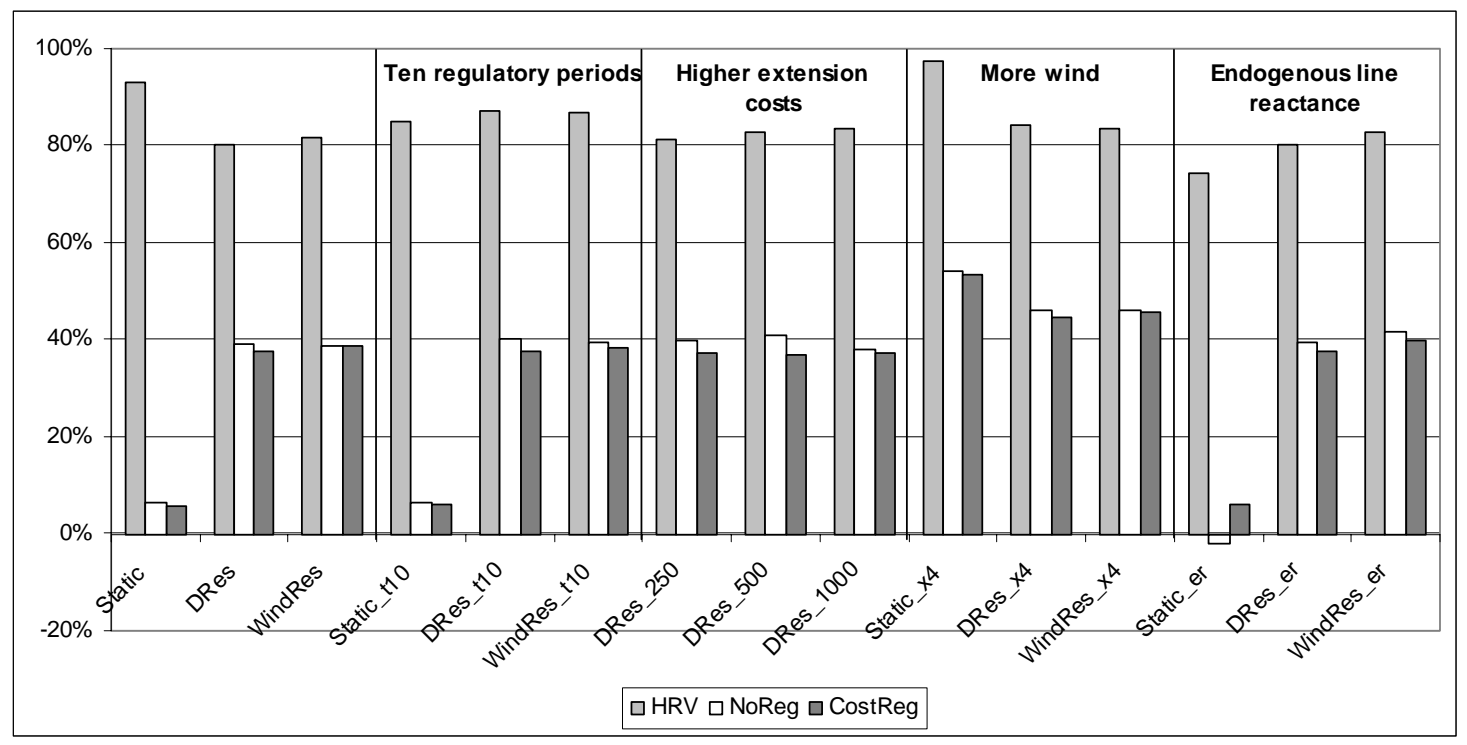


Conclusions

We have studied the performance of different regulatory regimes for transmission network expansion in the light of realistic demand patterns and fluctuating wind generation by applying them to a power-flow model of the central European transmission network. In contrast to earlier research, we explicitly include both an hourly time resolution and fluctuating wind power, which substantially increases the real-world applicability of the different approaches. In doing so, we have also adapted the HRV model so as to incorporate the peculiarities of large-scale RES systems, especially regarding wind power. Mathematically, the problem was formulated as an MPEC model (mathematical problem with equilibrium constraints). Such an application of the HRV mechanism to wind power goes beyond the existing literature which focuses on markets with traditional (mostly fossil fuel) electricity generation only. However, applying the existing HRV regulatory model to markets with large-scale RES requires some strong assumptions (e.g., on the volatility of wind and the short-term dispatching needs) which calls for a future extension of the current model.

Drawing on realistic demand levels, reference prices, and generation capacities, we showed that network extension in central Europe relieves existing congestion and thus increases social welfare. However, this also leads to a large redistribution of social welfare from consumers to producers in France and Germany. Comparing different regulatory approaches, we find that HRV regulation leads to extension and welfare outcomes close to the social optimum. HRV's welfare outcomes are far superior to the modelled alternatives of cost-based regulation (CostReg) and a merchant-like approach without additional investment incentives (NoReg). This result is robust over all modelled cases. NoReg leads to inferior welfare results because the Transco finds only very small line extensions profitable. Under cost-based regulation, less congested lines are thoroughly expanded, but there are substantial underinvestments for the most congested ones. In contrast, the HRV-mechanism provides the Transco with incentives to expand the network such that congestion is relieved. Accordingly, our numerical results support the theoretical claim by Hogan et al. (2010) that HRV regulation aligns the Transco's incentives with social welfare objectives.

From our analysis, we draw both methodological and policy-related conclusions. On a methodological level, we conclude that details matter in electricity transmission network modeling. In particular, analyzing the realworld implications of different regulatory approaches to transmission expansion requires a detailed representation of fluctuating electricity demand. Only then it is possible to achieve robust results on the location and the level of line upgrades, and the related welfare implications, in particular 
the relation of welfare gains, extension costs and fixed income of the Transco. In contrast, a simplified approach systematically underestimates the need for transmission upgrades. We also find that the effect of fluctuating wind power is of minor importance compared to demand fluctuations -at least at the current level of installed wind capacity in central Europe. Drawing on a range of sensitivity analyses, we also show that some simplifications are justified in order to maintain acceptable execution time.

Another more general theoretical problem of performance-based regulatory mechanisms is their inconsistency with timing issues of transmission networks. A framework based on the distinction of ultra-short periods, short periods and long periods would then be especially useful in future applications (Vogelsang, 2006). These timing frameworks are especially relevant for the application of regulatory PBR mechanisms - such as the HRV model- to electricity systems characterized by short and varying time resolution dispatching such as those systems based on renewable (wind, PV, CSP, etc.) energy. There exists a gap in the literature on such analysis that future research would like to fill out.

Finally, we also draw some policy conclusions. Given our numerical results, we cannot expect that a Transco in central Europe invests properly in transmission lines without being granted additional incentives. Accordingly, the modeled NoReg approach is not a preferable option for real-world policy makers. Yet cost-based regulation following our CostReg approach is an even less promising option, as it does not provide sufficient incentives for the Transco to invest in the most important lines. In addition, cost-based regulation requires the regulator to have substantial information on network congestion. In contrast, HRV regulation is an option that leaves extension decisions completely to the profit-maximizing Transco, while at the same time leading to desirable welfare outcomes. Moreover, we have shown that its beneficial welfare properties are very robust against fluctuations of demand and wind feed-in. In the light of future large-scale wind integration requirements, HRV regulation may also have favorable characteristics, as it triggers relatively high network extension. In the real world, the large-scale integration of wind power is not only constrained by limited transmission capacity, but also by imperfect foresight and thermal ramping restrictions. Although we did not model these aspects, it is clear that the large network expansion triggered by HRV regulation is generally good for wind integration.

It should be noticed that that the benefits of HRV regulation are related to a relatively large fixed tariff part. The fixed part constitutes a transfer from the Transco's variable income (congestion rents) to its fixed income. Our analysis, however, shows that the fixed part is larger than congestion rent losses, such that overall Transco profit increases substantially. According to our results, the Transco receives the major part of extension-related welfare gains, a distributive issue that can be addressed through the proper choice of 
weight of profits in the welfare criterion. Likewise, the real-world benefits of HRV regulation as modeled in this paper are put into question by the existence of imperfectly competitive dispatch in European electricity markets, which may interfere with the optimal HRV expansion paths calculated in this analysis. Last, but not least, HRV regulation would have to be reconciled with the political reality of incentive regulation, which has only recently been introduced in most European countries. For the time being, policy makers in Europe resort to theoretically less efficient, but practically enforceable approaches, at least regarding to such transmission projects that are most urgently required for the integration of renewable energy.

Further research projects in these issues would then be especially timely given the current policy efforts to achieve RES integration within Europe as well as the political progress towards the creation of a fully functional European energy regulator. A leading novel approach on incentive mechanism design for energy transmission networks would be particularly relevant for Europe, where less sophisticated regulatory mechanisms applied so far have not yielded sufficient transmission investment. The European Union is in fact in the process of elaborating a roadmap document (due in 2011) that establishes detailed de-carbonization strategies until 2050, including necessary infrastructure developments for RES large-scale systems. Formal research on the interdependency of renewable energy and electricity transmission pricing and investment is highly relevant for these developments. 
Appendix

TABLE 7. SETS AND I NDI CES, PARAMETERS, VARI ABLES

SYMBOL

DESCRI PTI ON

UNIT

Sets and indices:

$n, n n \in N$

$l \in \mathrm{L}$

$s \in S$

$\mathrm{t} \in \mathrm{T}$

$\tau \in \mathrm{T}$

Nodes

Line

Generation technology

Regulatory time periods

Dispatch time periods

hours

\section{Parameters:}

$m_{n, \tau}$

$a_{n, \tau}$

Slope of demand function

\begin{tabular}{|l|l|}
\hline $\bar{g}_{n, s}$ & \\
\hline$C_{s}$ &
\end{tabular}

$C_{s}$

$e c_{l}$

$\varepsilon$

$P_{l}^{0}$

\begin{tabular}{|l|}
$I_{l, n}$ \\
\hline$X^{0}$
\end{tabular}

$X_{l}^{0}$

$B_{n, n n, t}$

Intercept of demand function

Maximum hourly generation capacity

Variable generation costs

Line extension costs

Price elasticity of demand at reference point

Initial line capacity

Incidence matrix

Initial line reactance

slack $_{n}$

$\delta^{s}$

$\delta^{p}$

$r$

Variables:

$w f$

$\Pi$

Network susceptance matrix of period $t$

Slack node ( 1 for one node, 0 for all others)

Social discount rate

Private discount rate

Return on costs (in case of cost-based regulation)

\begin{tabular}{|l|}
\hline$q_{n, t, \tau}$ \\
\hline$g_{n, s, t, \tau}$ \\
\hline
\end{tabular}

$p_{n, t, \tau}$

$\Delta_{n, t, \tau}$

$\lambda_{1, l, t, \tau}$

$\lambda_{2, l, t, \tau}$

$p_{n, t, \tau}=\lambda_{3, n, t, \tau}$

\section{Overall welfare}

Transco profit

Hourly demand

Hourly generation

Hourly electricity price

Voltage angle

Shadow price of positive line capacity constraint

Shadow price of negative line capacity constraint

Shadow price of market clearing constraint (electricity price) 
J uan Rosellón, Wolf-Peter Schill and J onas Egerer

\begin{tabular}{|l|l|l|}
\hline \multicolumn{1}{|c|}{ SYMBOL } & \multicolumn{1}{|c|}{ DESCRI PTION } & \multicolumn{1}{c|}{ UNIT } \\
\hline$\lambda_{4, n, s, t, \tau}$ & Shadow price of generation capacity constraint & \\
\hline$\lambda_{5, n, t, \tau}$ & Shadow price of slack constraint & \\
\hline$e x t_{l, t}$ & Line extension & \\
\hline$P_{t, t}$ & Line capacity of period $t$ & MW \\
\hline$X_{l, t}$ & Line reactance of period $t$ & $\Omega$ \\
\hline fixpart $_{t}^{\text {CostReg }}$ & Fix tariff part in case of cost-based regulation & $€$ \\
\hline fixpart $_{t}^{\text {HRV }}$ & Fix tariff part in case of HRV regulation & $€$ \\
\hline
\end{tabular}

ISO's constrained welfa re maximization problem

$$
\begin{aligned}
& \max _{\substack{q, g, \Delta, \lambda_{1},,_{2}, p, \lambda_{3}, \lambda_{4},}} \sum_{t \in T}\left(\sum_{\tau \in \mathrm{T}} \sum_{n \in N}\left(\int_{0}^{q_{n, t, \tau}^{*}} p_{n, t, \tau}\left(q_{n, t, \tau}\right) d q_{n, t, \tau}-\sum_{s \in S} c_{s} g_{s, n, t, \tau}\right) \frac{1}{\left(1+\delta_{s}\right)^{t-1}}\right) \\
& \text { s.t. } \sum_{n} \frac{I_{l, n}}{X_{l, t}} \Delta_{n, t, \tau}-P_{l, t} \leq 0 \quad\left(\lambda_{1, l, t, \tau}\right) \quad \forall l, t, \tau \\
& -\sum_{n} \frac{I_{l, n}}{X_{l, t}} \Delta_{n, t, \tau}-P_{l, t} \leq 0 \quad\left(\lambda_{2, l, t, \tau}\right) \quad \forall l, t, \tau \\
& \sum_{s} g_{n, s, t, \tau}-\sum_{n n} B_{n, n n} \Delta_{n n, t, \tau}-q_{n, t, \tau}=0\left(p_{n, t, \tau}\right) \quad \forall n, t, \tau \\
& g_{n, s, t, \tau}-\bar{g}_{n, s} \leq 0 \quad\left(\lambda_{4, n, s, t, \tau}\right) \quad \forall n, s, t, \tau \\
& \operatorname{slack}_{n} \Delta_{n, t, \tau}=0 \quad\left(\lambda_{5, n, t, \tau}\right) \quad \forall n, t, \tau
\end{aligned}
$$

\section{Generation capacity at different nodes}

TABLE 8. GENERATION CAPACITY AT DI FFERENT NODES I N MW

\begin{tabular}{|l|r|r|r|r|r|r|r|r|r|}
\hline & NUCLEAR & LI GNI TE & $\begin{array}{l}\text { HARD } \\
\text { COAL }\end{array}$ & CCGT & $\begin{array}{c}\text { GAS } \\
\text { TURBINE }\end{array}$ & OIL & HYDRO & WI ND & OVERALL \\
\hline GER & 14,750 & 15,120 & 19,800 & 8,024 & 7,480 & 5,576 & 1,403 & 23,895 & 96,048 \\
\hline F & 45,547 & 0 & 10,440 & 748 & 4,522 & 2,312 & 8,394 & 3,422 & 75,385 \\
\hline BE1 & 2,976 & 0 & 1,226 & 1,667 & 482 & 1,040 & 32 & 162 & 7,586 \\
\hline BE2 & 1,218 & 0 & 502 & 683 & 198 & 426 & 13 & 162 & 3,201 \\
\hline NL1 & 236 & 0 & 1,994 & 3,372 & 2,321 & 2,080 & 0 & 716 & 10,720 \\
\hline NL2 & 47 & 0 & 400 & 677 & 466 & 418 & 0 & 716 & 2,724 \\
\hline NL3 & 83 & 0 & 702 & 1,187 & 817 & 732 & 0 & 716 & 4,238 \\
\hline OVERALL & 64,858 & 15,120 & 35,064 & 16,358 & 16,286 & 12,584 & 9,841 & 29,790 & 199,902 \\
\hline
\end{tabular}




\section{Price convergence in DRes}

FIGURE 18: CONVERGENCE OF HOURLY NODAL PRI CES UNDER DI FFERENT REGULATORY APPROACHES IN DRES
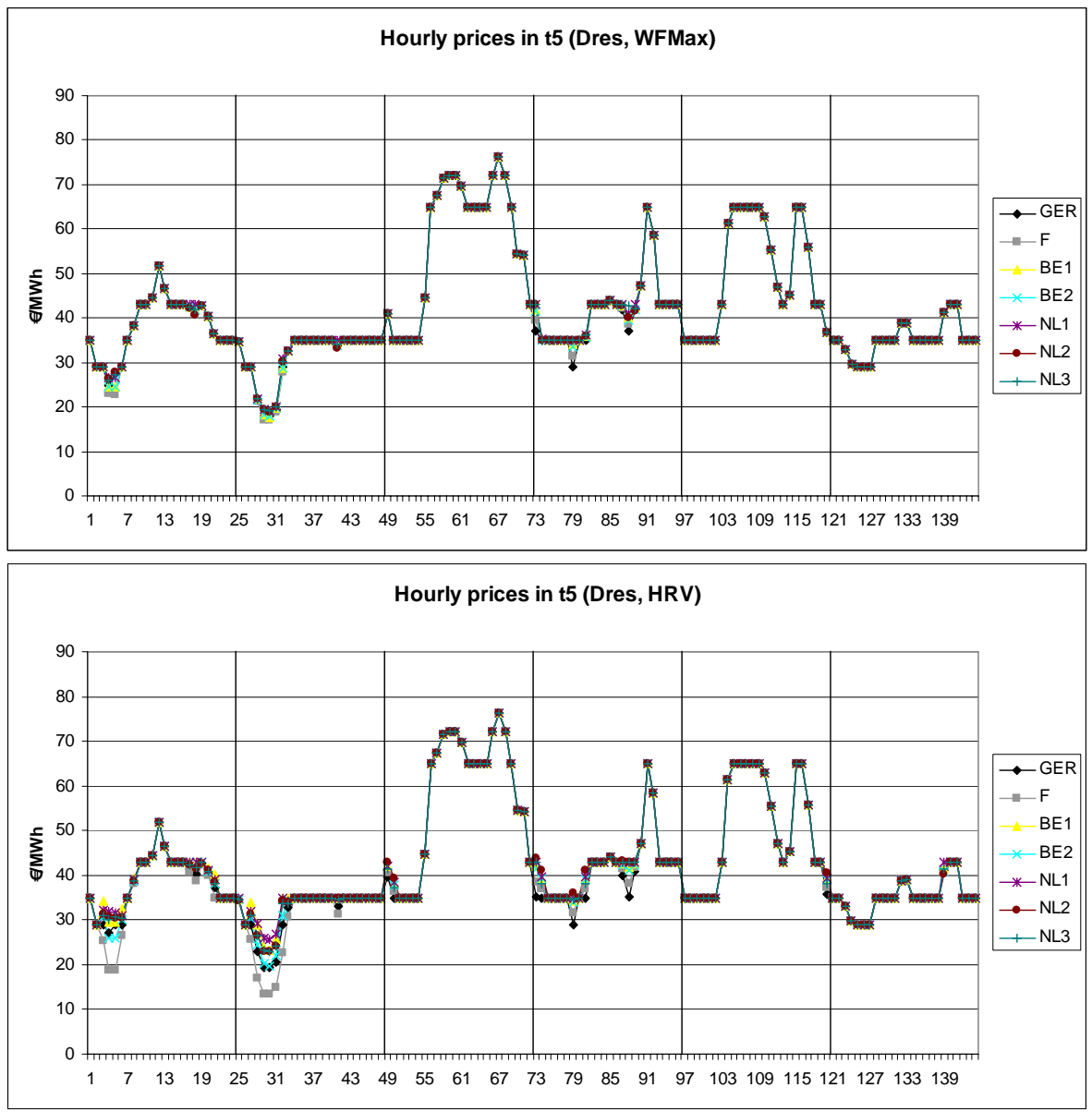

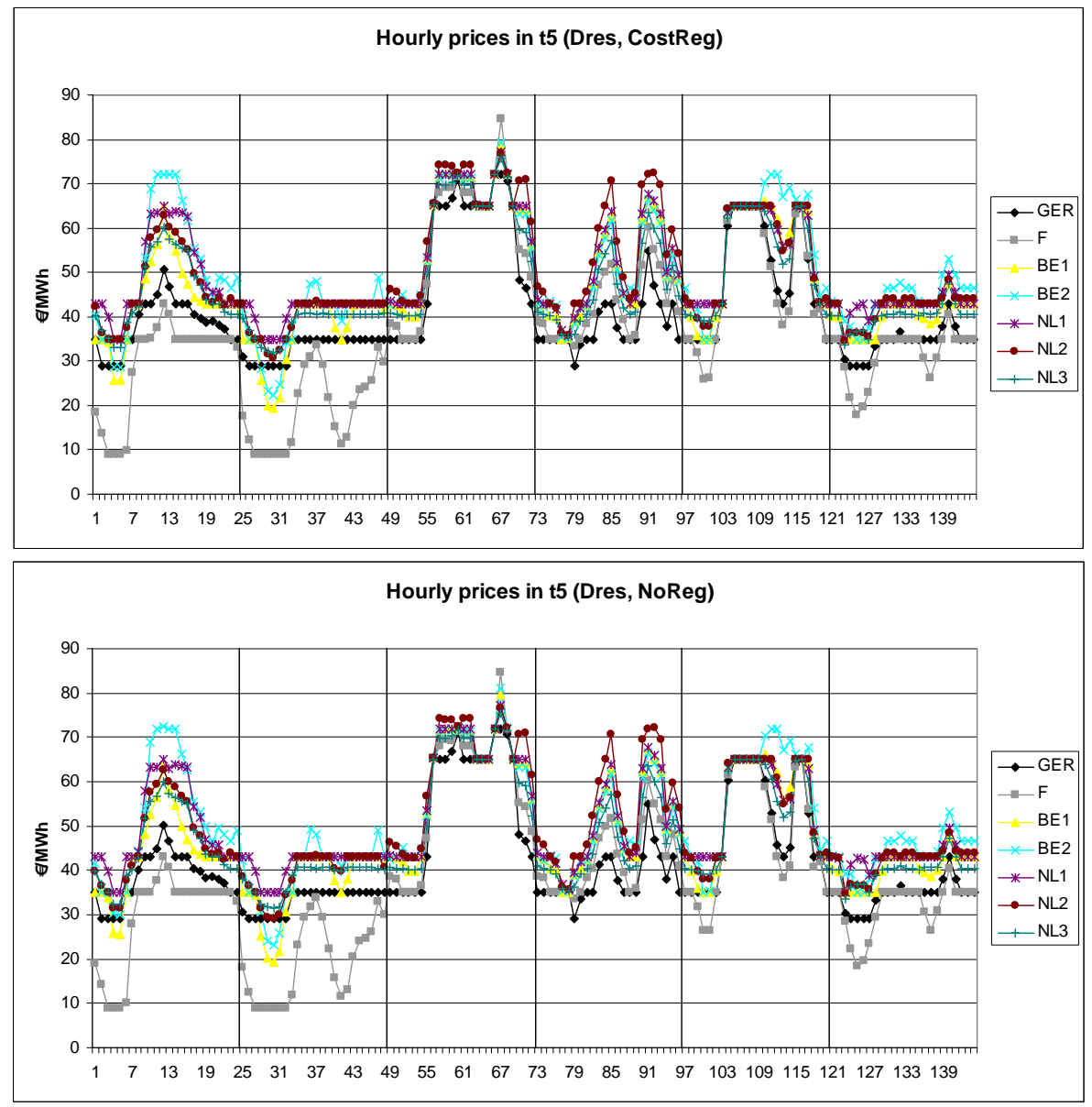


\section{Effect of endogenous line reactance on extension results}

FIGURE 19: LINE EXTENSION DIFFERENCES BETWEEN ENDOGENOUS AND EXOGENOUS REACTANCE FOR STATIC, DRES, AND WI NDRES
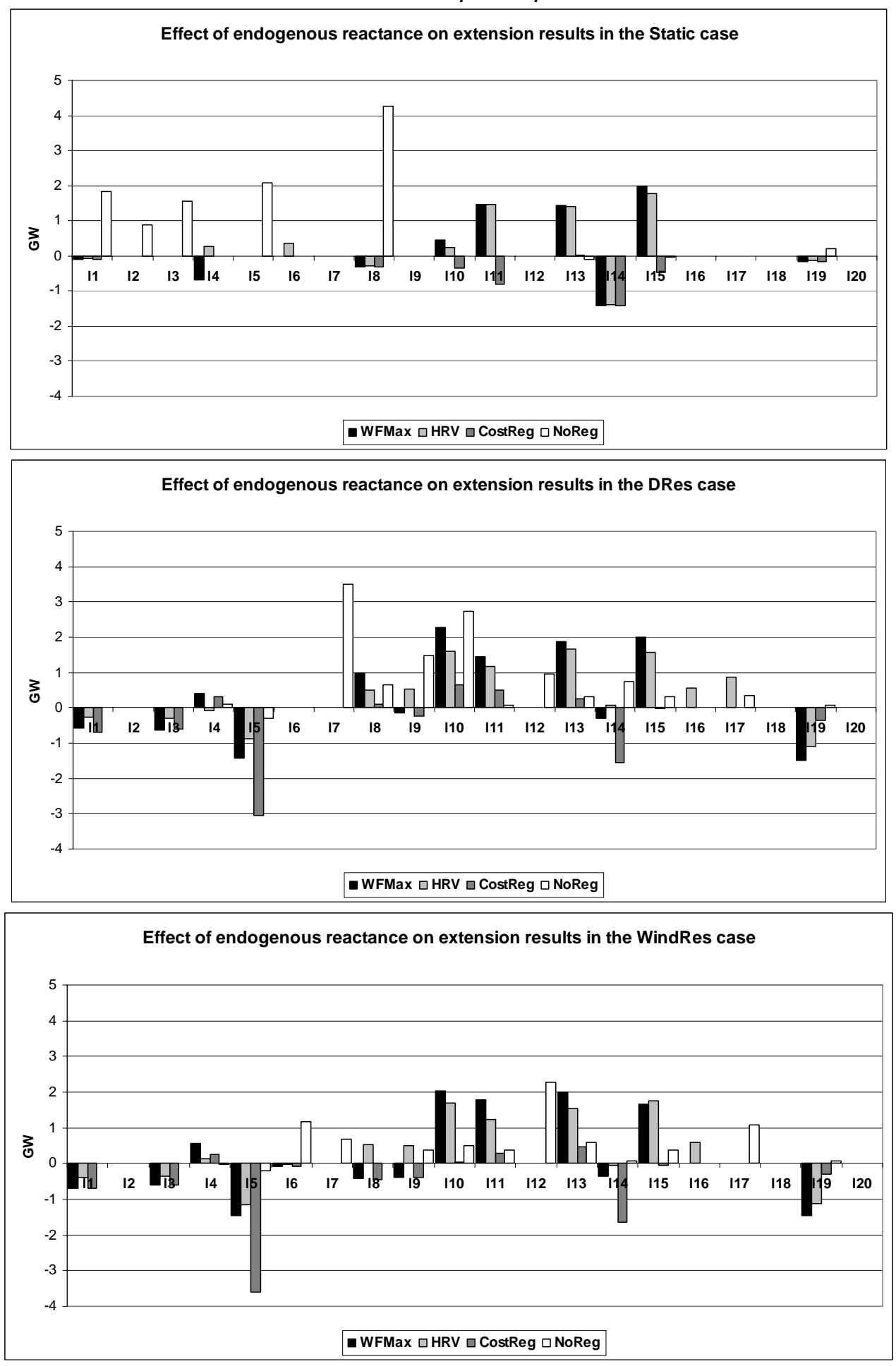
Armstrong M., S. Cowan and J. Vickers (1994), Regulatory reform: economic analysis and British experience, MIT, Cambridge.

BP (2010), BP Statistical Review of World Energy 2010; last accessed 31 J anuary 2011:

http:/ / www.bp.com/ statisticalreview

Bushnell, J. B. and S. E. Stoft (1997), "Improving private incentives for electric grid investment", Resource and Energy Economics, 19: 85-108.

Crew, M. A., C. S. Fernando and P. R. Kleindorfer (1995), "The theory of peakload pricing: a survey", J ournal of Regulatory Economics, 8: 215-48).

EEX (2010), EU Emission Allowances-spot market; last accessed 12 February 2011: http:/ / www.eex.com/ de/ marktdaten/ handelsdaten/ emissionsrechte

ENTSO-E (2010a), Net Generating Capacity on December 31st (in MW); last accessed 31 J anuary 2011:

https:/ / www. entsoe. eu/ db-query/ miscellaneous/ net-generating-capacity

Eurostat (2010), Infrastructure -electricity- annual data [nrg_113a], Last update: 23-09-2010; last accessed 31 J anuary:

http:/ / appsso. eurostat. ec. europa.eu/ nui/ show.do?dataset=nrg_113a\&lang=en

Gabriel, S. A. and Leuthold F. U. (2010), "Solving discretely-constrained MPEC problems with applications in electric power markets", Energy Economics, 32 (1) 3-14.

Grande, O. S. and I. Wangesteen (2000), "Alternative models for congestion management and pricing impact on network planning and physical operation", CIGRE 37-203-2000, Paris, August/ September.

Hobbs, B. F., C. B. Metzler and J. S. Pang (2000), "Strategic gaming analysis for electric power systems: an MPEC approach", IEEE Transactions on Power Systems, 15 (2), 638-645.

Hogan, W., J. Rosellón and I. Vogelsang (2010), "Toward a Combined MerchantRegulatory Mechanism for Electricity Transmission Expansion", Journal of Regulatory Economics, 38(2), 113-143.

IEA (2010), Projected Costs of Generating Electricity. International Energy Agency. Paris, 2010.

J ordanger J . and H. Grønli (2000), "Deregulation of the Electricity Supply Industry. Norwegian Experience 1991-2000", The Foundation for Scientific and Industrial Research at the Norwegian Institute of Technology (SINTEF), Norway: http:/ / www. energy. sintef. no/ avd/ Kraftnett/ Deregulation. htm

J oskow, P. and J. Tirole (2005), "Merchant transmission investment", J ournal of Industrial Economics, 53 (2), 233-264

Kristiansen, T. and J. Rosellón (2010), "Merchant mechanism electricity transmission expansion: a European case study", Energy, Volume 35, Issue 10, October 2010, pp. 4107-4115.

(2006), "A merchant mechanism for electricity transmission expansion", J ournal of Regulatory Economics, 29 (2), 167-193.

Léautier, T. O. (2000), "Regulation of an electric power transmission company", The Energy J ournal, 21: 61-92. 
Léautier, T. O. and V. Thelen (2009), "Optimal transmission expansion of the power transmission grid: why not?", J ournal of Regulatory Economics, 36 (2): 127-153.

Leuthold, F., H. Weigt and C. V. Hirschhausen (2008), ELMOD -A Model of the European Electricity Market. Electricity Markets Working Papers WP-EM-00, TU Dresden; last accessed 31 J anuary 2011:

http:// www.tu-dresden.de/ wwbwleeg/ publications/ wp_em_00_ELMOD. pdf

Neuhoff, K., J. B. Maroeska, G. Bootsc, A. Ehrenmannd, B. F. Höbbs, F. A. M. Rijkersf and M. Vázquez (2005), "Network-Constrained Cournot Models of Liberalized Electricity Markets: The Devil Is in the Details", Energy Economics 27: 495-525.

Rosellón, J. and H. Weigt (2011), "A Dynamic Incentive Mechanism for Transmission Expansion in Electricity Networks. Theory, Modeling and Application", The Energy J ournal, vol. 32, no. 1.

Rosellón, J., Z. Myslíková and E. Zenón (2011), "Incentives for Transmission Investment in the PJM Electricity Market: FTRs or Regulation (or both?)", Utilities Policy, vol. 19 (1), J anuary 2011, pp. 3-13.

Schweppe, F. C., Caramanis M. C., Tabors R. D., Bohn R. E. (1988), Spot Pricing of Electricity. Kluwer Academic Publishers, Boston/ Dordrecht/ London.

Vogelsang, I. (2006) "Electricity Transmission Pricing and Performance-Based Regulation", The Energy J ournal, vol. 27, no. 4.

(2001), "Price regulation for independent transmission companies", J ournal of Regulatory Economics, 20 (2): 141-165. 



\section{DIVISIÓN DE ADMINISTRACIÓN PÚBLICA}

Ma. Amparo Casar, Representation and Decision Making in the Mexican Congress, DTAP-258

Guillermo Cejudo y Dirk Zavala, Procesos y prácticas del acceso a la información: un ejercicio de usuario simulado, DTAP-257

Ernesto Flores-Roux y J udith Mariscal, The Development of Mobile Money Systems, DTAP-256

David Arellano et al., Control de los conflictos de interés, DTAP-255

David Arellano, Víctor Figueras y Walter Lepore, Política de tránsito en el DF de México: una introducción a su estudio empírico, DTAP-254

Sergio Cárdenas y Maximiliano Cárdenas, La participación del poder legislativo en la definición de la política educativa en México, DTAP-253

Sergio Cárdenas, Administración centrada en la escuela, DTAP-252

J oanna D. Lucio, Edgar Ramírez y Sergio Cárdenas, ¿Libertad para quién? El efecto de comunidades cerradas en el espacio urbano, DTAP-251

Edgar E. Ramírez, Land Development Permitting, DTAP-250

Rodrigo Sandoval-Almazán, Luis F. Luna-Reyes y J. Ramón Gil-García, Índice de Gobierno Electrónico Estatal: La medición 2009, DTAP-249

\section{DIVISIÓN DE ECONOMÍA}

Rafael Garduño-Rivera and Esteban Fernández-Vázquez, Ecological Inference with Entropy Econometrics: Using the Mexican Census as a Benchmark, DTE-511

Rafael Garduño, Kathy Baylis and Mary P. Arends-Kuenning, Regional Economic Analysis of Internal Migration in Mexico, DTE-510

Brasil Acosta Peña and Andrés Aradillas López, Semi-Empirical Likelihood Estimation of Manufacturing Interaction-Based Model..., DTE-509

Brasil Acosta Peña, Technical Efficiency in the Mexican Manufacturing Sector: A Stochastic Frontier Approach, DTE-508

Brasil Acosta Peña, Estimation of a Multiple Equilibrium Game with Complete Information..., DTE-507

Juan Rosellón, Anne Neumann and Hannes Weigt, Removing Cross-Border Capacity Bottlenecks in the European Natural Gas Market..., DTE-506

Alejandro López and J avier Parada, Poverty Dynamics in Rural Mexico: An Analysis Using Four Generations of Poverty Measurement, DTE-505

Kaniska Dam and Antonio Jiménez-Martínez, A Note on Bargaining over Complementary Pieces of Information in Networks, DTE-504

David Mayer y Grodecz Ramírez, Ciclo de vida humano y ciclo de vida urbano: Urbanización y desarrollo económico, DTE-503

Kaniska Dam y Daniel Ruiz Pérez, On the Existence of Sharecropping, DTE-502 


\section{DIVISIÓN DE ESTUDIOS INTERNACIONALES}

Rafael Velázquez, La política exterior de Estados Unidos hacia México bajo la administración de Barack Obama, DTEI-220

Rafael Velázquez y Jorge Schiavon, La cooperación internacional descentralizada para el desarrollo en México, DTEl-219

Kimberly A. Nolan García, Whose Preferences?: Latin American Trade Promotion Pacts as a Tool of US Foreign Policy, DTEl-218

Farid Kahhat, Rodrigo Morales y Ana Paula Peñalva, El Perú, las Américas y el Mundo. Opinión pública y política exterior en Perú, 2010, DTEl-217

Guadalupe González, J orge Schiavon, David Crow y Gerardo Maldonado, Mexico, the Americas and the World 2010..., DTEl-216

Guadalupe González, J orge Schiavon, David Crow y Gerardo Maldonado, México, Ias Américas y el Mundo 2010. Política exterior: Opinión pública y líderes, DTEl-215

Gerardo Maldonado, Desapego político y desafección institucional en México: ¿Desafíos para la calidad de la democracia?, DTEI-214

Luz María de la Mora, Opening Markets without Reciprocity: Explaining Mexico's Trade Policy, 2000-2010, DTEl-213

Farid Kahhat, Las industrias extractivas y sus implicaciones políticas y económicas, DTEI-212

Mariana Magaldi de Sousa, Trade Openness and the Channels of its Impact on Democracy, DTEI-211

\section{DIVISIÓN DE ESTUDIOS J URÍDICOS}

María Mercedes Albornoz , Cooperación interamericana en materia de restitución de menores, DTEJ -56

Marcelo Bergman, Crimen y desempleo en México: ¿Una correlación espuria?, DTEJ 55

Jimena Moreno, Xiao Recio y Cynthia Michel, La conservación del acuario del mundo. Alternativas y recomendaciones para el Golfo de California, DTEJ -54

María Solange Maqueo, Mecanismos de tutela de los derechos de los beneficiarios, DTEJ -53

Rodolfo Sarsfield, The Mordida's Game. How institutions incentive corruption, DTEJ -52

Ángela Guerrero, Alejandro Madrazo, J osé Cruz y Tania Ramírez, Identificación de las estrategias de la industria tabacalera en México, DTEJ -51

Estefanía Vela, Current Abortion Regulation in Mexico, DTEJ -50

Adriana García and Alejandro Tello, Salaries, Appelate Jurisdiction and Judges Performance, DTEJ - 49

Ana Elena Fierro and Adriana García, Design Matters: The Case of Mexican Administrative Courts, DTEJ -48

Gustavo Fondevila, Estudio de percepción de magistrados del servicio de administración de justicia familiar en el Distrito Federal, DTEJ -47 


\section{DIVISIÓN DE EsTUDIOS POLÍTICOS}

Ana Carolina Garriga, Regulatory Lags, Liberalization, and Vulnerability to Systemic Banking Crises, DTEP-232

Rosario Aguilar, The Tones of Democratic Challenges: Skin Color and Race in Mexico, DTEP-231

Rosario Aguilar, Social and Political Consequences of Stereotypes Related to Racial Phenotypes in Mexico, DTEP-230

Raúl C. González and Caitlin Milazzo, An Argument for the 'Best Loser' Principle in Mexico, DTEP-229

Francisco Javier Aparicio and Covadonga Meseguer, Supply or Demand? Politics and the 3x1 Program for Migrants, DTEP-228

Ana Carolina Garriga and Brian J. Phillips, Foreign Aid and Investment in PostConflict Countries, DTEP-227

Allyson Benton, The Origins of Mexico's Municipal Usos y Costumbres Regimes, DTEP226

Ana Carolina Garriga, Objetivos, instrumentos y resultados de política monetaria. México 1980-2010, DTEP-225

Andreas Schedler, The Limits to Bureaucratic Measurement. Observation and J udgment in Comparative Political Data Development, DTEP-224

Andrea Pozas and Julio Ríos, Constituted Powers in Constitution-Making Processes.

Supreme Court Judges, Constitutional Reform and the Design of Judicial Councils, DTEP-223

\section{DIVISIÓN DE HISTORIA}

Michael Sauter, Human Space: The Rise of Euclidism and the Construction of an Early-Modern World, 1400-1800, DTH-75

Michael Sauter, Strangers to the World: Astronomy and the Birth of Anthropology in the Eighteenth Century, DTH-74

J ean Meyer, Una revista curial antisemita en el siglo XIX: Civiltá Cattolica, DTH-73

J ean Meyer, Dos siglos, dos naciones: México y Francia, 1810- 2010, DTH-72

Adriana Luna, La era legislativa en Nápoles: De soberanías y tradiciones, DTH-71

Adriana Luna, El surgimiento de la Escuela de Economía Política Napolitana, DTH-70

Pablo Mijangos, La historiografía jurídica mexicana durante los últimos veinte años, DTH-69

Sergio Visacovsky, "Hasta la próxima crisis". Historia cíclica, virtudes genealógicas y la identidad de clase media entre los afectados por la debacle financiera en la Argentina (2001-2002), DTH-68

Rafael Rojas, El debate de la Independencia. Opinión pública y guerra civil en México (1808-1830), DTH-67

Michael Sauter, The Liminality of Man: Astronomy and the Birth of Anthropology in the Eighteenth Century, DTH-66 
EI CIDE es una institución de educación superior especializada particularmente en las disciplinas de Economía, Administración Pública, Estudios Internacionales, Estudios Políticos, Historia y Estudios Jurídicos. El Centro publica, como producto del ejercicio intelectual de sus investigadores, libros, documentos de trabajo, y cuatro revistas especializadas: Gestión y Política Pública, Política y Gobierno, Economía Mexicana Nueva Época e Istor.

Para adquirir cualquiera de estas publicaciones, le ofrecemos las siguientes opciones:

\section{VENTAS DIRECTAS:}

\section{VENTAS EN LÍNEA:}

Tel. Directo: $5081-4003$

Tel: $5727-9800$ Ext. 6094 y 6091

Fax: 57279800 Ext. 6314

Av. Constituyentes 1046, ler piso,

Col. Lomas Altas, Del. Álvaro Obregón, 11950, México, D.F.

Librería virtual: www.e-cide.com

Dudas y comentarios: publicaciones@cide.edu

\section{¡iColecciones completas!!}

Adquiere los CDs de las colecciones completas de los documentos de trabajo de todas las divisiones académicas del CIDE: Economía, Administración Pública, Estudios Internacionales, Estudios Políticos, Historia y Estudios J urídicos.
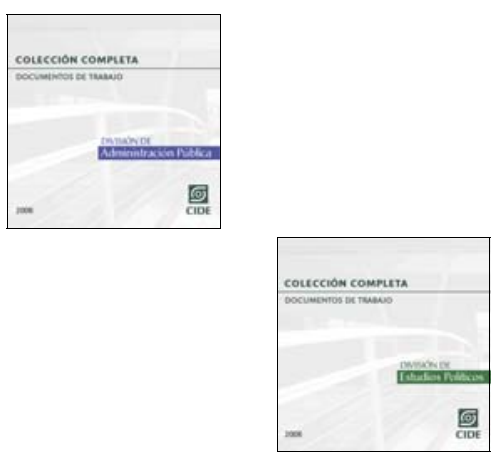
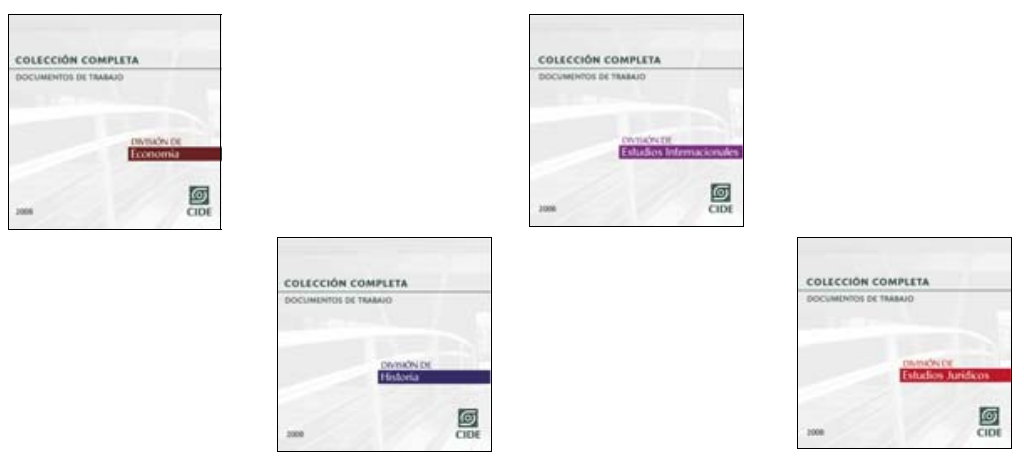

\section{¡Nuevo! ¡¡Arma tu CD!!}

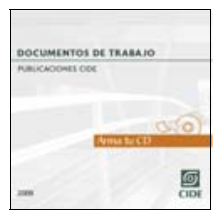

Visita nuestra Librería Virtual www.e-cide.com y selecciona entre 10 y 20 documentos de trabajo. A partir de tu lista te enviaremos un CD con los documentos que elegiste. 